\title{
Identification of Specific mRNAs Affected by Treatments Producing Long-Term Facilitation in Aplysia
}

Raymond E. Zwartjes, ${ }^{1}$ Henry West, ${ }^{1}$ Samer Hattar, ${ }^{1}$ Xiaoyun Ren, ${ }^{1}$ Florence Noel, ${ }^{2}$ Marta Nuñez-Regueiro, ${ }^{1}$ Kathleen MacPhee, ${ }^{1}$ Ramin Homayouni, ${ }^{1}$ Michael T. Crow, ${ }^{3}$ John H. Byrne, ${ }^{2}$ and Arnold Eskin ${ }^{1,4}$

${ }^{1}$ Department of Biochemical and Biophysical Sciences

University of Houston

Houston, Texas 77204-5934

${ }^{2}$ Department of Neurobiology and Anatomy

University of Texas-Houston Medical School

Houston, Texas 77030

${ }^{3}$ Gerontology Research Center

National Institute on Aging

National Institutes of Health

Baltimore, Maryland 21224

\begin{abstract}
Neural correlates of long-term sensitization of defensive withdrawal reflexes in Aplysia occur in sensory neurons in the pleural ganglia and can be mimicked by exposure of these neurons to serotonin (5-HT). Studies using inhibitors indicate that transcription is necessary for production of long-term facilitation by $5-\mathrm{HT}$. Several mRNAs that change in response to 5-HT have been identified, but the molecular events responsible for long-term facilitation have not yet been fully described. To detect additional changes in mRNAs, we investigated the effects of 5-HT (1.5 hr) on levels of mRNA in pleural-pedal ganglia using in vitro translation. Four mRNAs were affected by 5-HT, three of which were identified as calmodulin (CaM), phosphoglycerate kinase (PGK), and a novel gene product (protein 3). Using RNase protection assays, we found that 5-HT increased all three mRNAs in the pleural sensory neurons. CaM and protein 3 mRNAs were also increased in the sensory neurons
\end{abstract}

${ }^{4}$ Corresponding author. by sensitization training. Furthermore, stimulation of peripheral nerves of pleural-pedal ganglia, an in vitro analog of sensitization training, increased the incorporation of labeled amino acids into CaM, PGK, and protein 3. These results indicate that increases in CaM, PGK, and protein 3 are part of the early response of sensory neurons to stimuli that produce long-term facilitation, and that CaM and protein 3 could have a role in the generation of long-term sensitization.

\section{Introduction}

Evidence has been accumulating for some time indicating that protein synthesis is required for the formation of long-term memory (Davis and Squire 1984). More recently, the use of models for learning that can be studied at both the behavioral and molecular levels indicates changes in gene transcription are required for the induction of longterm memory (Nelson and Alkon 1990; Anokhin and Rose 1991; Bourtchuladze et al. 1994; Yin et al. 1994). Additional evidence for the involvement of transcription has come from studying sensitization, a form of nonassociative learning, in Aplysia. Components of the defensive withdrawal reflexes, which are modified by sensitization, can be studied

LEARNING \& MEMORY 4:478-495 @ 1998 by Cold Spring Harbor Laboratory Press ISSN1072-0502/98 \$5.00

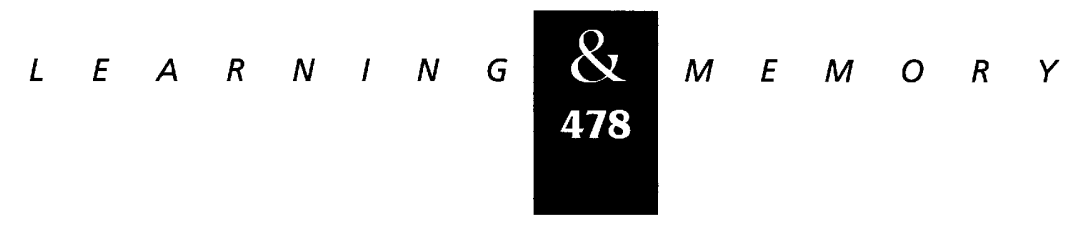


in vitro using isolated ganglia or cultured sensory and motor neurons (for review, see Castellucci and Schacher 1990; Byrne et al. 1993). The induction by serotonin [5-hydroxytryptamine hydrochloride (5-HT)] of long-term facilitation (LTF) at the connections between sensory and motor neurons in culture was blocked by inhibitors of transcription or translation applied during the inducing treatments (Montarolo et al. 1986).

The results from subsequent studies further support a role for transcription in the generation of LTF. The transcription inhibitor actinomycin D blocked 5-HT-produced increases in the incorporation of labeled amino acids into proteins (Barzilai et al. 1989) and blocked the persistent phosphorylation of proteins found $24 \mathrm{hr}$ after 5-HT treatments (Sweatt and Kandel 1989). In addition, the injection of an oligodeoxynucleotide containing a cAMP response element (CRE) into sensory neurons in culture blocked the induction of LTF by 5-HT (Dash et al. 1990). Finally, CCAAT/enhancer-binding protein (C/EBP) is induced by 5-HT, and inhibiting its function blocks LTF (Alberini et al. 1994).

The results of the above studies with inhibitors indicate that transcription is, in some way, involved in the production of LTF. To fully understand LTF and the role of transcription, it is necessary to know the pathway through which 5-HT affects gene expression and the mechanism by which genes regulated by 5 -HT mediate the production of LTF. In addition to C/EBP, several other mRNAs affected by 5-HT have been identified. Most of the proteins encoded by these mRNAs have not been clearly linked to LTF. Ubiquitin hydroxylase was shown to be important for the establishment of LTF (Hegde et al. 1997). Aplysia tolloid may also contribute to LTF (Liu et al. 1997; Zhang et al. 1997). However, many aspects of the mechanisms for the generation of LTF remain unclear.

To identify additional proteins that might contribute to the production of LTF, we investigated changes in levels of mRNA following treatment with 5-HT. We used in vitro translation (IVT) of cellular mRNAs followed by two-dimensional polyacrylamide gel electrophoresis (2-D PAGE) of the protein products. This technique allows the determination of the relative amount of translatable mRNA for individual proteins within a complex mixture of mRNAs (Colbert and Young 1986, 1987; Coleclough et al. 1990; Miles et al. 1992). We found that 5-HT altered four mRNAs in pleuralpedal ganglia, three of which we identified: cal- modulin (CaM), phosphoglycerate kinase (PGK), and a novel gene (protein 3). CaM, PGK, and protein 3 mRNAs also increased in pleural sensory neurons following treatment with 5-HT, although only CaM and protein 3 were increased by sensitization training. In addition, an in vitro analog of training increased incorporation of labeled amino acids into all three proteins in sensory neurons. These results indicate that $\mathrm{CaM}$ and protein 3 could have a role in the generation of long-term sensitization.

\section{Materials and Methods}

\section{5-HT TREATMENT OF GANGLIA AND BEHAVIORAL SENSITIZATION}

Twelve animals were used for each IVT experiment, and four to six animals were used for ribonuclease protection assays (RPAs). Isolated ganglia were treated for $1.5 \mathrm{hr}$ with $5 \mu \mathrm{M}$-HT (Sigma, St. Louis, MO) and then frozen, essentially as described in Noel et al. (1991) but without $\left[{ }^{35}\right.$ S]methionine. Sensitization training consisted of four blocks of electrical shocks over $1.5 \mathrm{hr}$ delivered to the posterior body wall (Scholz and Byrne 1987; W.L. Lee, M. Aguirre, L.J. Cleary, and J.H. Byrne, unpubl.). Animals were anesthetized immediately after treatment; ganglia were then removed and frozen.

\section{RNA EXTRACTION FROM GANGLIA AND IVT}

RNA was extracted from ganglia by homogenization in phenol (Ambion, Austin, TX) and SDS (Sigma) at $65^{\circ} \mathrm{C}$, followed by two extractions with phenol/chloroform (50:50) and precipitation with ethanol. The ethanol precipitate was reconstituted in water and reprecipitated with $2 \mathrm{~m}$ sodium acetate ( $\mathrm{pH}$ 6). Poly(A) ${ }^{+}$RNA was isolated on an oligo(dT) column as described by Sambrook et al. (1989). IVT was done using rabbit reticulocyte lysate (nuclease treated, minus methionine; Promega Corp., Madison, WI) in the presence of $\left[{ }^{35} \mathrm{~S}\right] \mathrm{me}$ thionine essentially following the supplier's protocol, except that $5 \mathrm{~mm}$ cAMP (Sigma) was added to prevent inactivation of eukaryotic initiation factor 2 (Gross et al. 1988). Reactions were carried out at $30^{\circ} \mathrm{C}$ for $2 \mathrm{hr}$. Canine pancreatic microsomal membranes were obtained from Promega and used as instructed by the supplier.

\section{2-D PAGE}

Aliquots of IVT lysate were added to 6 volumes

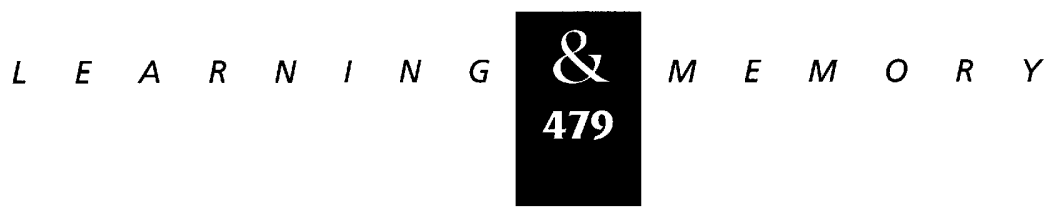


of solubilization buffer and analyzed by 2-D PAGE, as described in Zwartjes and Eskin (1990) except that the ampholytes (Pharmacia, Piscataway, NJ) used were $\mathrm{pH}$ 2.5-5, 4-6.5, and 3-10 in a ratio of $1: 2: 2$. In addition, gels were treated with Autofluor (National Diagnostics, Atlanta, GA) before drying. The fluorographs were first analyzed visually, and spots were designated as changing or unchanging, followed by analysis using a computerized densitometer (DNA Proscan, Nashville, TN). The ratios of optical densities of the visually identified unchanging spots from experimental and control gels were determined to confirm that they were not affected by the treatment. The optical densities of the visually identified changing spots were then determined and normalized for any discrepancy in gel loading by expressing them as a percentage of the sum of the optical densities of the verified unchanging spots. The difference in values between experimental and control spots was then determined. Because these differences were not normally distributed, the two-tailed Wilcoxon's Matched-pairs Signed-rank test was used-a nonparametric test of significance. In accordance with this test, the experimental results are expressed as median values and the variation is expressed as the quartile coefficient of variation (VQ).

\section{DETERMINATION OF $\left[{ }^{35}\right.$ S]METHIONINE INCORPORATION INTO IN VITRO-TRANSLATED PROTEINS}

Total RNA ranging from 2.5 to $40 \mu \mathrm{g}$ was translated in vitro, and the incorporation of ${ }^{35} \mathrm{~S}$ into trichloroacetic acid (TCA; Sigma) precipitable material was determined. The amount of incorporation was linear over this range. TCA precipitation was performed as follows: $2 \mu \mathrm{l}$ of lysate, in triplicate, was incubated at $37^{\circ} \mathrm{C}$ for $10 \mathrm{~min}$ in $250 \mathrm{ml}$ of $0.1 \mathrm{M} \mathrm{NaOH}, 2 \% \mathrm{H}_{2} \mathrm{O}_{2}$. On ice, $0.5 \mathrm{ml}$ each of 0.3 $\mathrm{mg} / \mathrm{ml} \mathrm{BSA} \mathrm{(Sigma)} \mathrm{and} \mathrm{50 \%} \mathrm{TCA} \mathrm{were} \mathrm{added.} \mathrm{Af-}$ ter $30 \mathrm{~min}$, precipitate was collected on Whatman GF/A filters and counted in $5 \mathrm{ml}$ of scintillation fluid.

\section{RNASE H DIGESTION OF}

OLIGONUCLEOTIDE-HYBRIDIZED RNA

Five micrograms of total RNA from pleuralpedal ganglia, with or without $200 \mathrm{ng}$ of CaM oligonucleotide, was heated to $60^{\circ} \mathrm{C}$ for $10 \mathrm{~min}$, cooled on ice, and hybridized at room temperature for $1 \mathrm{hr}$. The hybridization buffer contained 100 mм KCl, 20 mм HEPES (pH 7.0), 1 mм EDTA (Minshull and Hunt 1986). The synthesized oligodeoxynucleotide was complementary to nucleotides 238-261 of the protein-coding region of the Aplysia CaM mRNA (Swanson et al. 1990). One volume of $2 \times$ RNase $H$ reaction buffer [ $16 \mathrm{U} / \mathrm{ml}$ of RNase $\mathrm{H}, 100 \mathrm{~mm} \mathrm{KCl}, 40 \mathrm{~mm}$ Tris-Cl (pH 7.6), $3 \mathrm{~mm}$ $\mathrm{MgCl}_{2}, 100 \mathrm{mg} / \mathrm{ml}$ glycogen, $2 \mathrm{~mm}$ dithiothrietol (all from Sigma)] was added to each sample. Samples were incubated at $37^{\circ} \mathrm{C}$ for $1 \mathrm{hr}$ and precipitated with ethanol. The RNA was translated in vitro and the proteins analyzed by 2-D PAGE as described above.

\section{WESTERN BLOTS}

For CaM, two pleural-pedal ganglia were incubated with $\left[{ }^{35} \mathrm{~S}\right]$ methionine $(0.15 \mu \mathrm{Ci} / \mathrm{ml})$ for $2 \mathrm{hr}$. The labeled proteins were separated by 2-D PAGE as above, except that the ampholytes for isoelec-

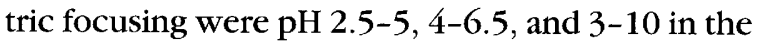
ratio of $2: 2: 1$. The proteins were then transferred to polyvinylidene fluoride membrane (Immobilon$\mathrm{P}$, Millipore, Bedford, MA) in $25 \mathrm{~mm} \mathrm{KPO}_{4}(\mathrm{pH}$ 7.0 ), for $18 \mathrm{hr}$ at $20 \mathrm{~V}$. The membrane was probed with a polyclonal anti-rat CaM antibody (provided by Dr. A.R. Means, Duke University, Durham, NC). An alkaline phosphatase-conjugated secondary antibody was used (Jackson Immunoresearch Lab., West Grove, PA). The blot was developed with aminoethylcarbazole (Sigma) as substrate. X-ray film was exposed to the dried membrane to produce an autoradiograph.

For PGK, a mouse anti-yeast PGK antibody was used (pgk 1C9, kindly provided by Dr. R.S. Molday, University of British Columbia, Vancouver; Hsu and Molday 1991). Abdominal ganglion proteins were labeled as above and $120 \mu \mathrm{g}$ was separated by 2-D PAGE using ampholytes of $\mathrm{pH} 4-6.5$ and 3-10 in a ratio of 2:3. Following transfer and primary antibody binding, an alkaline phosphatase-conjugated secondary antibody (Sigma) was bound and visualized using BCIP/NBT as substrate (AP Chromagen Kit, Biomeda Corp., Foster City, CA). An autoradiograph was then made of the blot.

\section{COMIGRATION OF PROTEINS IN 2-D GELS}

Purified chicken CaM (provided by Dr. A.R. Means) was run on 2-D gels (as for the CaM blot

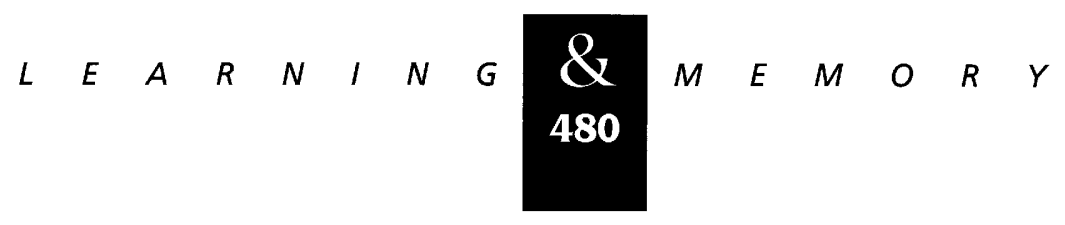


above) with and without $\left[{ }^{35} \mathrm{~S}\right]$ methionine-labeled pleural-pedal proteins. The gels were stained with Coomassie brilliant blue G-250 (CBB; Bio-Rad, Richmond, CA) and dried. An autoradiograph was then made from the gel.

\section{PEPTIDE SEQUENCING}

Peptides for sequencing were obtained using methods described by Kennedy et al. (1988) and Raju et al. (1993). Abdominal ganglia were used as a source of protein because insufficient protein was obtained from sensory neurons and the yield of soluble protein from pleural-pedal ganglia per mass of tissue is much less than that from abdominal ganglia. Care was taken to ensure that proteins sequenced from the abdominal ganglia matched precisely with those of the pleural-pedal ganglia in 2-D gels. Approximately $450 \mu \mathrm{g}$ of protein was run on each of 24 preparative 2-D gels and stained with CBB R-250 (Bio-Rad). The proteins corresponding to proteins 2 and 3 were then excised from the gels and stored in $50 \%$ methanol at $-20^{\circ} \mathrm{C}$. Following rehydration, the gel pieces were ground in a solution containing $0.05 \mathrm{~m}$ Tris ( $\mathrm{pH} 6.8$ ), $0.1 \%$ SDS, $0.2 \%$ glycerol, $0.0006 \%$ bromophenol blue (Sigma), and $0.005 \mathrm{mg} / \mathrm{ml}$ Staphylococcus aureus V8 protease (Sigma, sequencing grade). The gel slurry was then loaded into a well of a 1-D gel (15\% acrylamide). After separating the peptides the gel was electroblotted onto ProBlott membrane (Applied Biosystems, Foster City, CA) in 0.01 м 3-cyclohexylamino-1-propanesulfonic acid (CAPS; Sigma) at $\mathrm{pH} 11.0$ and at $0.5 \mathrm{~A}$ for $1 \mathrm{hr}$. The membrane was stained with CBB R-250, and peptides were excised for sequencing in an Applied Biosystems pulsedliquid protein sequencer (model 477A). The resulting sequences were compared to the nonredundant database of the National Center for Biotechnology Information (NCBI) using the BLAST (Altschul et al. 1990) and the FASTA (Pearson and Lipman 1988) programs.

\section{PCR AMPLIFICATION OF PROTEIN 3 cDNA}

PCR primers were made based on the amino acid sequences obtained by peptide sequencing of protein 3. A degenerate forward primer (5'-GAYTGGGCHGAYGCNGARAC-3') was made to peptide 1 and a degenerate reverse primer (5'-GGCATNGTNGGRTTCAT-3') to peptide 2 (see Fig. 7 , below). RNA was extracted from Aplysia ganglia, and
poly(A) ${ }^{+}$RNA was isolated as described above. cDNA was synthesized using a cDNA synthesis kit (U.S. Biochemical, Cleveland, $\mathrm{OH}$ ).

PCR was performed using a GeneAmp PCR reagent kit (Perkin-Elmer, Foster City, CA). A mixture of $66 \mathrm{ng}$ of cDNA, $2 \mathrm{~mm}$ of each primer, $10 \mu \mathrm{l}$ of $10 \times$ reaction buffer, and $200 \mathrm{~mm}$ of each dNTP was heated to $94^{\circ} \mathrm{C}$ prior to the addition of 2.5 units of AmpliTaq enzyme in a total volume of $100 \mu \mathrm{l}$. The reaction was run in a PTC-100 Programmable Thermal Controller (MJ Research, Watertown, MA) for 25 cycles as follows: $93^{\circ} \mathrm{C}$ for $45 \mathrm{sec}, 45^{\circ} \mathrm{C}$ for 2 $\mathrm{min}$, and $60^{\circ} \mathrm{C}$ for $30 \mathrm{sec}$. A final extension step was performed at $72^{\circ} \mathrm{C}$ for $5 \mathrm{~min}$.

The PCR reaction was purified using Magic PCR Preps (Promega) and cloned using the TA cloning system (Invitrogen Corp., San Diego, CA). Positive clones were identified by restriction digest. The 134-bp insert was sequenced using a Sequenase kit (dideoxy method; U.S. Biochemical).

\section{LIBRARY SCREENING AND CLONING}

The Aplysia PGK clone was obtained by screening with human PGK I from the American Tissue Culture Collection (1.8 kb, PstI fragment). The probe was labeled with $\left[\alpha-{ }^{32} \mathrm{P}\right] \mathrm{dCTP}$ by random priming. Approximately 250,000 clones were screened from a cDNA library of Aplysia head ganglia (Dr. A. Kurosky, University of Texas Medical Branch, Galveston; Nagle et al. 1995). Duplicate filters were prepared, hybridized overnight at $42^{\circ} \mathrm{C}$ in hybridization buffer ( $50 \%$ formamide, $5 \times \mathrm{SSC}, 20$ $\mathrm{mm}$ Tris- $\mathrm{HCl}$ at $\mathrm{pH} 7.6,1 \times$ Denhardt's solution, $10 \%$ dextran sulfate, $0.1 \%$ SDS, $100 \mu \mathrm{g} / \mathrm{ml}$ salmon sperm DNA), and washed ( $1 \times \mathrm{SSC}, 0.1 \% \mathrm{SDS})$ at increments of $5^{\circ} \mathrm{C}$ from $45^{\circ} \mathrm{C}$ to $60^{\circ} \mathrm{C}$ at 15 -min intervals. Positive clones were subjected to an additional round of hybridization. Following purification of positive clones, pBluescript $\mathrm{SK}^{-}$phagemids containing cDNA inserts were generated by in vivo excision from the Lambda ZapII vector using the ExAssist-SOLR system (Stratagene, La Jolla, CA). Sequencing was done with Sequenase or by Taq Cycle Sequencing using DyeDeoxy Terminators (Applied Biosystems).

Protein 3 was first cloned by screening an Aplysia cDNA library (provided by Dr. P. Dash, University of Texas-Houston Medical School). The 134-bp PCR product described above was used as a probe. The clone contained rRNA sequence, in addition to sequence corresponding to the probe.

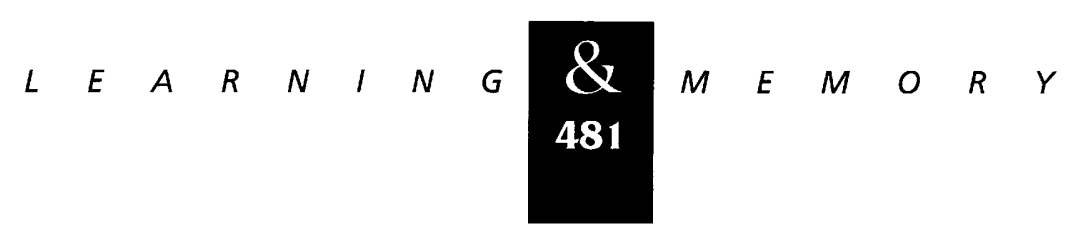


Zwartjes et al.

Therefore, a 300-bp probe encompassing the 134bp sequence was made from the clone by restriction digest at $E c o$ RI sites. This probe was then used to screen the head ganglia library. The sequences have been submitted to GenBank (accession nos. AF042738 for PGK and AF042739 for protein 3).

\section{CONSTRUCTS FOR RIBOPROBES}

Standard protocols were used for DNA manipulations (Sambrook et al. 1989). Some plasmid preparations were done with Magic Miniprep or Maxiprep kits (Promega). Restriction enzymes were obtained from Promega. All constructs were sequenced to verify the identity and orientation of the insert.

CaM riboprobe vector was produced by subcloning from an Aplysia CaM clone in pBluescript. Digestion with $K p n I$ and BalI was followed by blunt-end ligation of the filled $K p n I$ site with the Ball site. A BamHI fragment was then removed from the $5^{\prime}$ end to produce a 291-bp insert.

PGK riboprobe vector was produced from the full-length clone by PCR of nucleotides $(340 \mathrm{bp})$ in the $3^{\prime}$ end of the coding region, followed by cloning into the pOCUS T-vector (Novagen, Madison, WI) at the EcoRV sites.

Protein 3 was subcloned from the full-length clone into pBluescript by EcoRI digestion, isolation of a 1000-bp fragment, and ligation. Linearization with $P v u I I$ produces a 270 -bp protected fragment.

Aldolase was subcloned from a partial clone of Aplysia aldolase-B (R. Homayouni and A. Eskin, unpubl.). PCR was used to generate a fragment extending from the T3 site of pBluescript to a $K p n I$ site. The fragment was digested with $K p n I$ and SacI, purified, and ligated into pBluescript. The insert includes $130 \mathrm{bp}$ of aldolase sequence.

\section{RIBOPROBE PREPARATION}

Riboprobes were made with a MAXIscript kit (Ambion). Heat shock cognate protein [HSC70, 88nucleotide protected fragment, kindly provided by Drs. Kuhl and E. Kandel (Kuhl et al. 1992)], CaM, and aldolase were linearized with BamHI, PGK with HindIII, and protein 3 with PvuII. One microgram of linearized DNA, $\left[{ }^{32} \mathrm{P}\right] \mathrm{rUTP}$, and T3 RNA polymerase (HSC70) or T7 RNA polymerase (CaM, PGK, protein 3, aldolase) was used to synthesize the antisense transcripts. Transcripts were separated from unincorporated label on 5\% acryl- amide/8 $\mathrm{m}$ urea gels. Probes were radiolabeled to a specific activity of approximately $10^{7} \mathrm{cpm} / \mu \mathrm{g}$.

\section{RPAs}

Clusters of pleural sensory neurons were removed from ganglia while frozen in dry ice/propylene glycol/buffered filtered seawater (Eskin et al. 1989). Total RNA was extracted using the Stratagene RNA Isolation Kit, a variation of the method of Chomczinsky and Sacchi (1987). Using an RPA II kit (Ambion), RPAs were performed and analyzed as described (Liu et al. 1997). Control lanes were run with each RPA, including undigested riboprobes and a digested riboprobe/RNA mixture. HSC70 results were used to normalize the values of the mRNA being tested. Statistical analysis was done using a two-tailed paired t-test. The normal distribution of the RPA results allowed the use of a parametric test, in contrast to the IVT results.

RPAs for the tissue distribution of protein 3 were done as described above using RNA extracted from each of the tissues and riboprobes for protein 3 and HSC70. The rank order of expression of protein 3 mRNA in tissues was determined by its expression relative to $\mathrm{HSC} 70$.

\section{ELECTRICAL STIMULATION OF PLEURAL}

PEDAL GANGLIA

Electrical stimulation of the peripheral nerves of pleural-pedal ganglia was done as described in Noel et al. (1993). Briefly, isolated experimental ganglia from three animals were given four trains of electrical shock at 30-min intervals in the presence of $\left[{ }^{35} \mathrm{~S}\right]$ methionine; control, matched ganglia received no stimulation. The ganglia were frozen immediately after the last train, sensory clusters were removed while frozen, and the proteins analyzed by 2-D PAGE. A one-tailed Wilcoxon's Matched-pairs Signed-rank test was used to test significance.

\section{Results}

SEROTONIN AFFECTED FOUR mRNAS IN PLEURAL PEDAL GANGLIA

The sensory neurons which mediate the tailsiphon withdrawal reflex are located in the pleural ganglia (Walters et al. 1983a,b). Although our pri-

$$
\begin{array}{llllllllllllllll}
\hline & E & A & R & N & I & N & G & \underset{482}{\mathbf{Z}} & M & E & M & O & R & Y
\end{array}
$$


mary interest lies in mRNA changes in the sensory neurons (see below), we initially examined whole ganglia to obtain sufficient RNA for IVT. One pleural-pedal ganglion from each animal served as a control; the other was treated with 5-HT $(5 \mu \mathrm{M})$ for $1.5 \mathrm{hr}$. Treatments with serotonin of $1.5 \mathrm{hr}$ duration produce LTF of the tail sensory neuron to motor neuron connection (Emptage and Carew 1993; Zhang et al. 1997) and have been used previously as an in vitro analog of sensitization training (Barzilai et al. 1989; Eskin et al. 1989; Sweatt and Kandel 1989; Noel et al. 1991). At the end of the 5-HT treatment the ganglia were frozen, RNA was extracted, and poly $(\mathrm{A})^{+}$RNA was isolated and translated in vitro with rabbit reticulocyte lysate in the presence of $\left[{ }^{35} \mathrm{~S}\right]$ methionine. The labeled proteins were then separated by 2-D PAGE and analyzed by fluorography and computerized densitometry.

We first tested varying amounts of RNA in the translation assay and found that the total amount of label incorporated into protein was proportional to the amount of RNA added to the lysate over a wide range (not shown). We also compared the relative molecular weights $\left(M_{\mathrm{r}}\right)$ and isoelectric points $(\mathrm{pI})$ of proteins translated in vitro with those labeled with $\left[{ }^{35}\right.$ S]methionine in the intact ganglion. Approximately $30 \%$ of the in vitro-translated proteins had the same $M_{\mathrm{r}}$ and $\mathrm{pI}$ as in situ-labeled proteins. The low percentage of proteins with corresponding $M_{\mathrm{r}}$ and $\mathrm{pI}$ was due, in part, to the lack of posttranslational modifications occuring in the rabbit reticulocyte lysate. The addition of pancreatic microsomal membranes, which produce some signal peptide cleavage and glycosylation (Walter and Blobel 1983), increased the proportion of corresponding proteins to almost $50 \%$ (not shown). Experiments with 5-HT were done without microsomal membranes to avoid additional variability that may have been introduced by incomplete processing of the proteins.

Serotonin did not appear to produce a general increase or decrease in mRNA synthesis as determined by total incorporation of labeled amino acid into proteins. The mean experimental to control ratio of $\left[{ }^{35} \mathrm{~S}\right]$ methionine incorporation into TCAprecipitable material was $1.05(n=10)$ with a range of 0.54 to 1.60 . Most of this variability can probably be accounted for by losses during the manipulation of very small amounts of RNA.

Serotonin affected four specific mRNAs significantly. The incorporation of label consistently increased into three proteins and decreased into one protein when mRNA from 5 -HT-treated ganglia was translated, as compared to mRNA from untreated ganglia (Fig. 1; Table 1). Other changes may have occurred that were not detectable with this technique. For example, mRNA with a low copy number per cell or low efficiency of initiation may not produce enough protein in vitro to be detected in the fluorograph. Also, with the 2-D PAGE technique used, the ranges of protein $\mathrm{pI}, M_{\mathrm{r}}$, and labeling that appear in the fluorograph are limited. Therefore, not all mRNAs were assayed using this technique.

\section{ONE OF THE MRNAS AFFECTED BY 5-HT ENCODES CaM}

To further investigate the role of these changing mRNAs in LTF, we have identified three of the proteins encoded by the mRNAs. One of the four

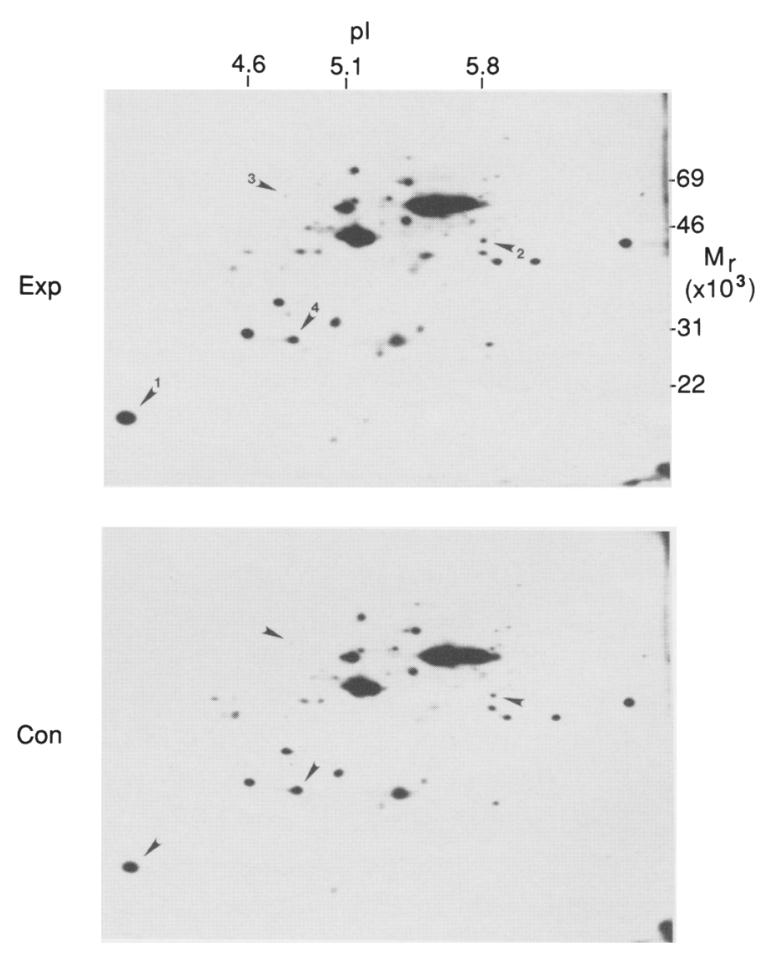

Figure 1: Effect of 5-HT treatment of ganglia on in vitro incorporation of $\left[{ }^{35} \mathrm{~S}\right]$ methionine into proteins translated from cellular mRNAs. Twelve experimental ganglia were treated with $5-\mathrm{HT}(5 \mu \mathrm{M})$ for $1.5 \mathrm{hr}$ and frozen at the end of treatment; untreated control ganglia were frozen at the same time. Poly $(\mathrm{A})^{+}$RNA was then isolated and translated in vitro. Incorporation was increased into three proteins (1,2, and 3) and decreased into one protein (4) when ganglia were treated with $5-\mathrm{HT}(\operatorname{Exp})$, as compared to untreated ganglia (Con) (see Table 1). Other apparent differences between proteins in the two fluorographs were not reproducible.

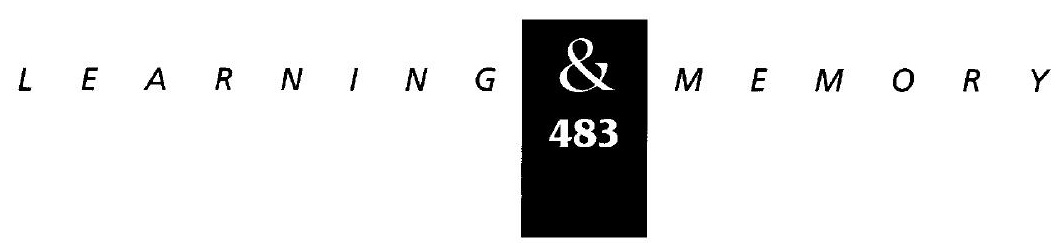


Zwartjes et al.

Table 1: Effects of treatments that produce LTF on the expression of MRNA as determined by IVT and RPAs

\begin{tabular}{|c|c|c|c|c|}
\hline \multirow[b]{2}{*}{ Protein } & \multirow[b]{2}{*}{$M_{\mathrm{r}} / \mathrm{pl}$} & \multicolumn{3}{|c|}{ Change in OD (\% of control) } \\
\hline & & $\begin{array}{l}\text { treatment: } 1.5 \text { hr } 5-\mathrm{HT} \\
\text { Method: IVT (ganglia) }\end{array}$ & $\begin{array}{l}1.5 \mathrm{hr} 5-\mathrm{HT} \\
\operatorname{RPA}(\mathrm{SN})^{\mathrm{b}}\end{array}$ & $\begin{array}{l}\text { training } \\
\text { RPA }(\mathrm{SN})^{\mathrm{b}}\end{array}$ \\
\hline 1 (CaM) & $17 K / 3.9$ & $\begin{array}{c}+71 \% \\
(P<0.05 ; \mathrm{VQ}=93 ; n=10)\end{array}$ & $\begin{array}{c}+71 \% \\
( \pm 9 ; n=7)\end{array}$ & $\begin{array}{c}+33 \% \\
( \pm 8 ; n=6)\end{array}$ \\
\hline 2 (PGK) & $42 \mathrm{~K} / 5.8$ & $\begin{array}{c}+46 \% \\
(P<0.05 ; \mathrm{VQ}=89 ; n=10)\end{array}$ & $\begin{array}{c}+32 \% \\
( \pm 9 ; n=10)\end{array}$ & $\begin{array}{c}-1 \% \\
( \pm 2 ; n=4)\end{array}$ \\
\hline 3 & $\begin{array}{l}61 K / 4.9 \\
29 K / 4.8\end{array}$ & $\begin{array}{c}+38 \% \\
(P<0.01 ; \mathrm{VQ}=57 ; n=10) \\
-19 \%\end{array}$ & $\begin{array}{c}+59 \% \\
( \pm 13 ; n=7)\end{array}$ & $\begin{array}{c}+41 \% \\
( \pm 10 ; n=6)\end{array}$ \\
\hline & & $(P<0.01 ; \mathrm{VQ}=39 ; n=10)$ & - & - \\
\hline apAldolase-B & & - & $\begin{array}{c}-8 \% \\
( \pm 4 ; n=3)\end{array}$ & - \\
\hline apTBL-1 ${ }^{c}$ & & - & $\begin{array}{c}+82 \% \\
( \pm 22 ; n=10)\end{array}$ & $\begin{array}{c}+29 \% \\
( \pm 8 ; n=10)\end{array}$ \\
\hline
\end{tabular}

${ }^{\text {aPoly }}(\mathrm{A})^{+}$RNA was isolated from $5-\mathrm{HT}$-treated and untreated ganglia and translated in vitro in the presence of $\left.{ }^{35} \mathrm{~S}\right] \mathrm{me}-$ thionine. The labeled proteins were separated by 2-D PAGE, and fluorographs were made from the gels. The fluorographs were scanned with a densitometer and the experimental and control protein optical densities (ODs) were compared. Statistical significance was evaluated as described in the text.

${ }^{b} \mathrm{RNA}$ was isolated from sensory neurons (SN) following treatment of the ganglia with 5-HT or following sensitization training. Riboprobes to the target mRNA and to HSC70 were hybridized with the RNA and then digested. The protected fragments were separated on gels and an autoradiograph was made from the gel. The film was scanned by a densitometer and the OD of the target mRNA was normalized using the OD of HSC70. Statistical significance was evaluated using a two-tailed paired $t$-test $(P<0.05$ in all cases). Values shown are \pm S.E.M.

'Data from Liu et al. (1997) for comparison.

mRNAs affected by 5-HT codes for a protein (protein 1, Fig. 1) with an $M_{\mathrm{r}}$ and $\mathrm{pI}(17,000$ and 3.9) similar to CaM. To determine whether the in vitrotranslated protein was produced from a CaM mRNA, CaM mRNA was selectively removed from pleural-pedal RNA before IVT. An oligodeoxynucleotide complementary to a portion of the coding region of the Aplysia CaM gene was hybridized to pleural-pedal RNA, RNase $\mathrm{H}$ was added to digest the RNA/DNA hybrids, and the RNA was translated in vitro. Inclusion of the oligodeoxynucleotide prior to RNase $\mathrm{H}$ digestion reduced incorporation only into the 17,000 , pI 3.9 protein demonstrating that the mRNA affected by 5 -HT codes for CaM (Fig. 2). Digestion was not allowed to go to completion to visualize CaM on the fluorograph. To determine whether the 17,000 , pI 3.9 protein translated in situ was also CaM, we analyzed pleural-pedal proteins by 2-D PAGE and Western blot. An anti-rat CaM antibody specifically recognized the 17,000 , pI 3.9 protein (Fig. 3). Furthermore, this protein comigrated with chicken CaM in 2-D gels (not shown). Thus, the in situ and in vitro- translated $17,000, \mathrm{pI} 3.9$ proteins both appear to be CaM.

\section{PROTEIN 2 IS PGK}

An in situ-labeled protein corresponding to the in vitro-translated protein 2 was located in 2-D gels, and a partial amino acid sequence was obtained from it using microsequencing techniques. The protein was excised from multiple preparative 2-D gels, and a partial digest was then done with V8 protease. The resulting peptides were separated by 1-D PAGE and electroblotted onto a membrane. One peptide band was excised from the membrane and subjected to pulsed-liquid microsequencing.

The sequence of 45 amino acids obtained from the protein was used to search the NCBI databases. The sequence was found to be $88 \%$ identical to human PGK II (Fig. 4; McCarrey and Thomas 1987). The $P$ value assigned by the BLAST program was $2.9 \times 10^{-25}$, indicating a very high probability that this match was not random. In addition, the peptide sequence had high percentages of identiti- 


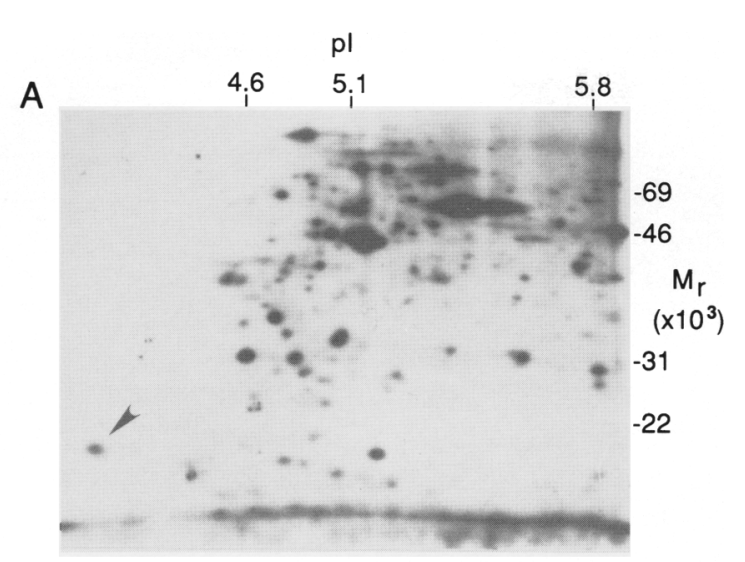

B

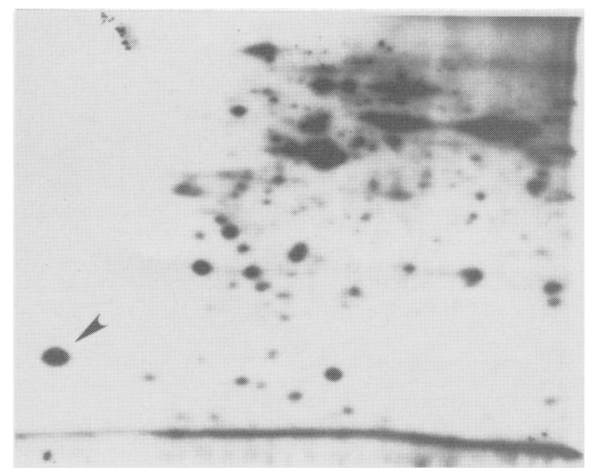

Figure 2: Identification of the $M_{r} 17,000$, pl 3.9 in vitro-translated protein as CaM. (A) Pleural-pedal RNA was hybridized to an oligodeoxynucleotide complementary to the coding region of the Aplysia CaM mRNA and digested with $\mathrm{RNase} H$ prior to being translated in vitro. (B) Pleural-pedal RNA was incubated with RNase $\mathrm{H}$ as in $A$ but without the complementary oligodeoxynucleotide. RNase $\mathrm{H}$ only digests hybridized RNA; therefore, the decrease in the amount of label incorporated into the $M_{\mathrm{r}} 17,000$, pl 3.9 protein (arrowhead) in $A$, as compared to $B$, indicates that this mRNA was hybridized to the antisense oligonucleotide and codes for CaM. No other protein was affected as reproducibly or to the degree that the $M_{r} 17,000$, pl 3.9 protein was diminished

cal amino acids when compared to PGK in numerous species ranging from bacteria, to yeast, to human. The $M_{\mathrm{r}}$ of protein $2(42,000)$ is similar to that of human PGK II (45,000; McCarrey and Thomas 1987). To confirm that the 42,000 , pI 5.8 ganglion protein is PGK, an antibody for yeast PGK was used to probe a 2-D Western blot of Aplysia abdominal ganglion proteins. The antibody recognized the 42,000 , pI 5.8 protein (Fig. 5).

To facilitate further study of the PGK mRNA, an Aplysia PGK cDNA was cloned from a library derived from the head ganglia. The human PGK I gene was used as a probe because it also shows high levels of identity to the Aplysia peptide and it was easily obtainable. The isolated cDNA codes for a protein of 415 amino acids with a $M_{\mathrm{r}}$ of 43,670 (Fig. 6). A BLAST search revealed rat PGK II (Ciccarese et al. 1989) to have the highest level of sequence identity with Aplysia PGK. The two proteins are $70 \%$ identical at the amino acid level.

\section{PROTEIN 3 IS A NOVEL PROTEIN}

Initially, a similar strategy of peptide sequencing was used to investigate protein 3 . Sequences of 28 and 30 amino acids were obtained from two peptides derived from the ganglion protein corresponding to protein 3 . Interestingly, when preparative 2-D gels were run, two proteins were resolved. Both proteins were digested and subjected to peptide sequencing, and were found to be identical. This finding is further considered below. Degener-

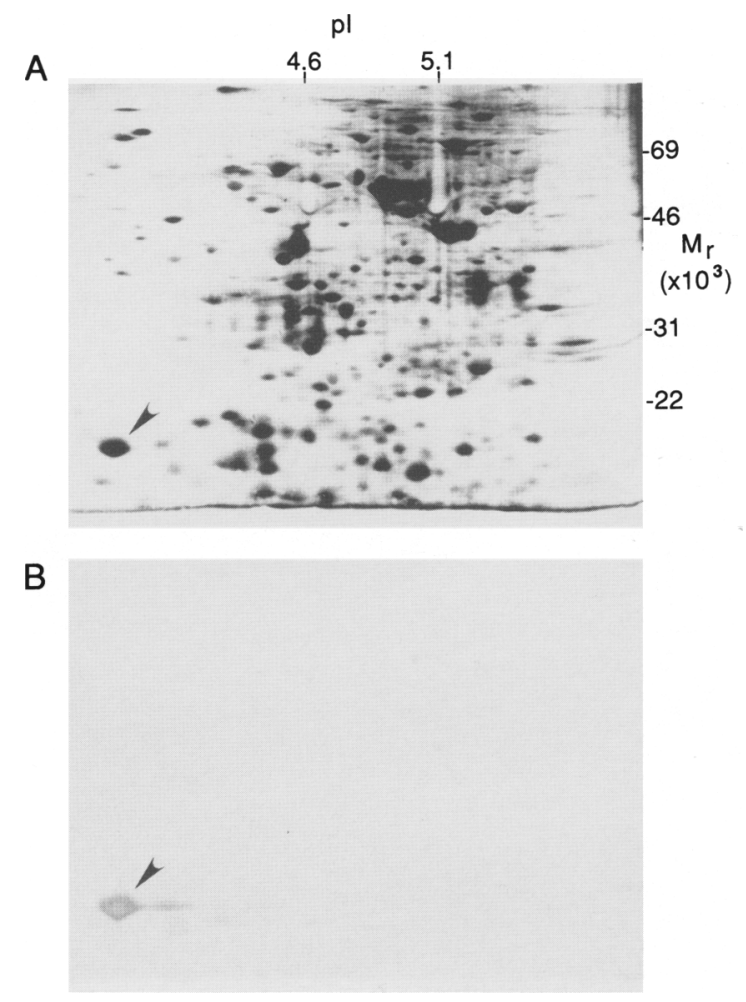

Figure 3: Identification of the $M_{r} 17,000, \mathrm{pl} 3.9$ protein in the pleural-pedal ganglia as CaM by Western blot analysis. (A) $\left.{ }^{35} \mathrm{~S}\right]$ Methionine-labeled proteins from pleural-pedal ganglia were blotted, and an autoradiograph was made from the membrane. $(B)$ The same membrane was probed with an anti-rat CaM antibody. The $M_{r} 17,000$, pl 3.9 protein was specifically recognized by the antibody (arrowheads).

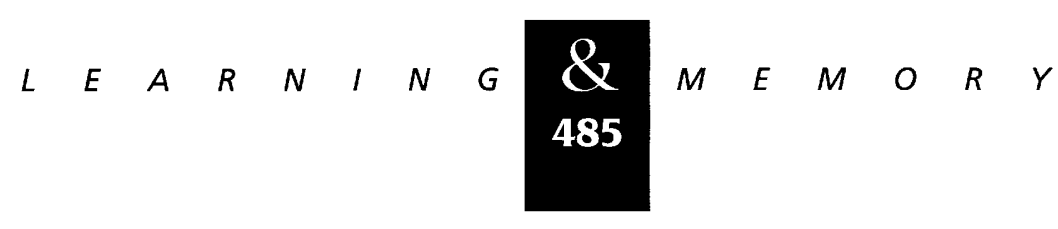


Zwartjes et al.

Figure 4: Amino acid sequence of a peptide derived from protein 2 , aligned with human PGK II and yeast PGK. Protein 2 was isolated from ganglia and digested with $\mathrm{V} 8$

HUman PGK II 194 LDYFAKALENPYRPFLAILGGAKVADKIQT TKNMDKVNGMIIGG 238

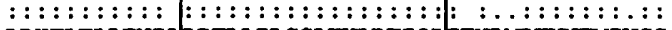

Aplysia peptide 1 IDYFAKALENEARPFLAILGGAKVADIQY ENLMDKNEMIVGG 45

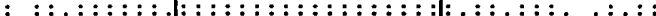

Yeast PGK 192 LKYFGRALENPTRPFLAILGGAKVADKIQUTDNLIDKVDSIIIGG 236 protease; one peptide was then sequenced. The boxed area has been shown to contribute to the ATP/ADP binding site (Watson et al. 1982) and is well conserved between species. Two dots indicate identical amino acids; one dot indicates a conservative substitution. Numbers indicate the positions of the end amino acids in the protein or peptide.

ate oligonucleotides were made based on portions of the sequences of the 28- and 30-amino-acid peptides (Fig. 7). The DNA sequence between the peptide coding regions was then amplified from Aplysia nervous system cDNA by PCR. The PCR product contained sequence coding for an additional 9 amino acids, for a total of 67 amino acids. Database searches with this sequence showed a match ( $45 \%$ identity) to a Caenorbabditis elegans ORF of unknown function, called "similar to reductase" (simred) (Wilson et al. 1994).

Next, we cloned a cDNA from an Aplysia li-

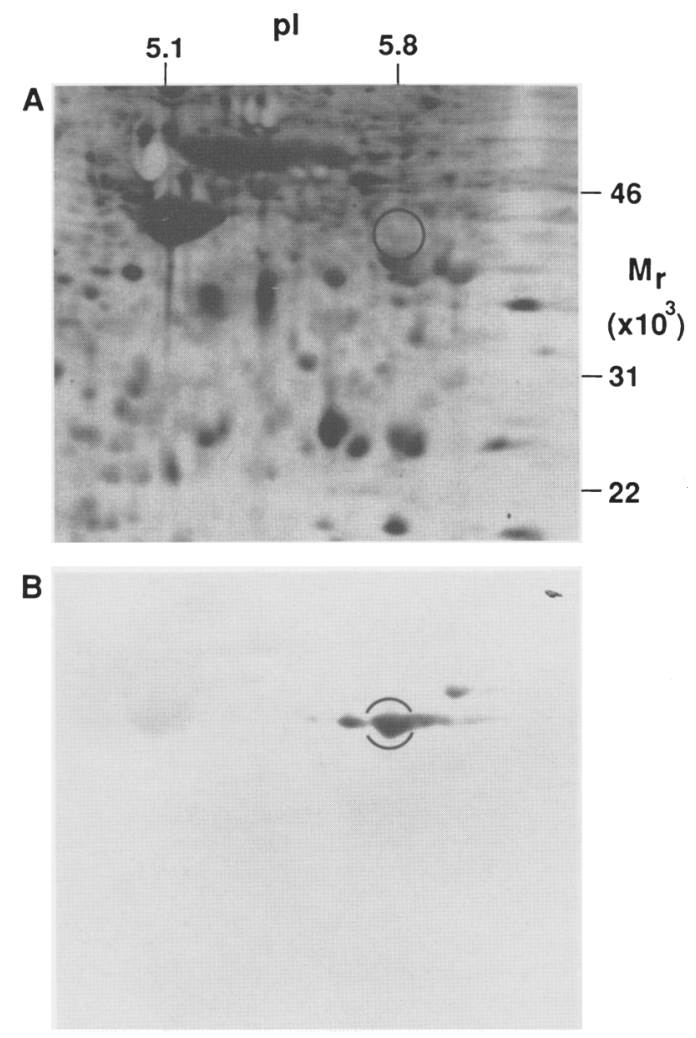

Figure 5: Identification of protein 2 as PGK by Western blot analysis. (A) $\left.{ }^{35} \mathrm{~S}\right]$ Methionine-labeled proteins from abdominal ganglia were blotted and an autoradiograph was made from the membrane. $(B)$ The same membrane was probed with an anti-yeast PGK antibody. Protein 2 (circled) was specifically recognized by the antibody. brary using the PCR product described above as a probe. The cDNA codes for a protein of $\mathbf{4 7 4}$ amino acids with a $M_{\mathrm{r}}$ of 51,430 and a pI of 5.36 (Fig. 7). Searches using the full-length sequence revealed low similarity to several proteins in the NCBI databases. The greatest similarity was to the C. elegans ORF noted above, followed by dihydroflavonol 4reductase (DFR) from the plant Arabidopsis

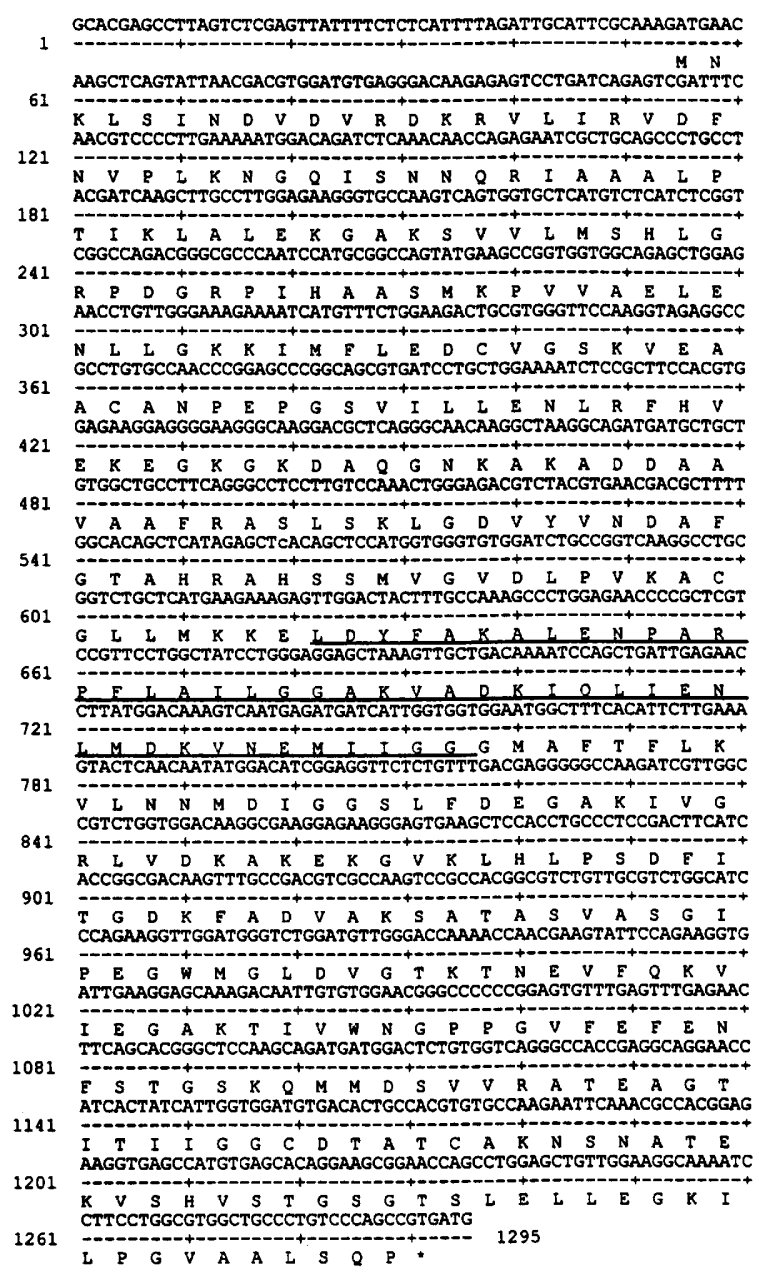

Figure 6: Nucleotide sequence of a cDNA coding for PGK and its amino acid translation. The cDNA was cloned from an Aplysia cDNA library using human PGK I gene as a probe. The peptide sequenced from protein 2 is underlined.

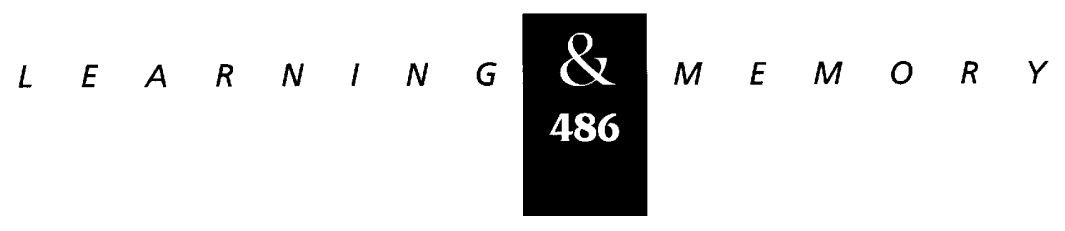




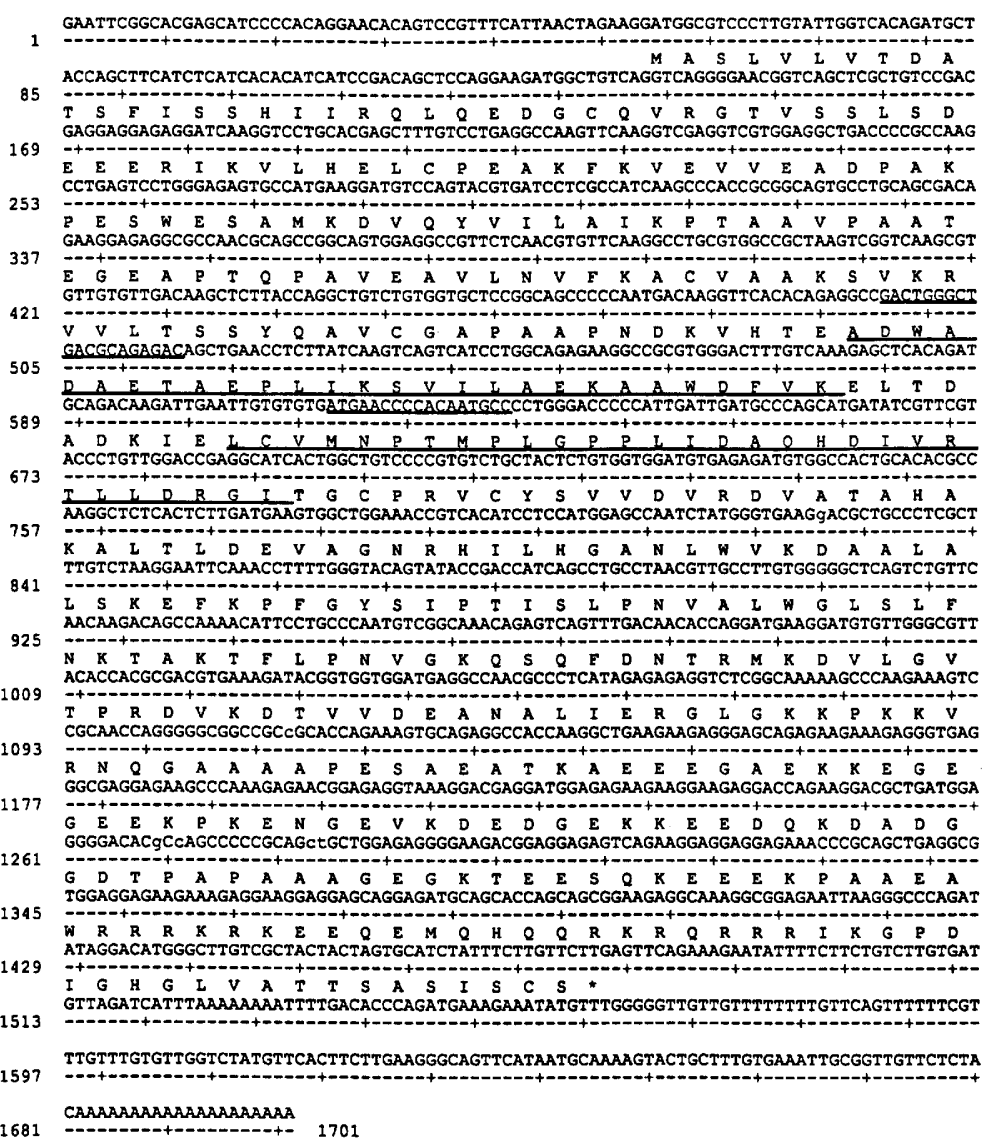

Figure 7: Nucleotide sequence of a cDNA coding for protein 3 and its amino acid translation. The cDNA was cloned from an Aplysia CDNA library using a PCR product obtained from degenerate primers as a probe. The degenerate primer sequences were derived from two peptides sequenced from protein 3 . The underlined nucleotide sequences correspond to the PCR primer sites. The underlined amino acid sequences denote the two peptides sequenced from the protein. thaliana (Shirley et al. 1992). This was followed by DFR from numerous other plants, four ORFs sequenced from Saccharomyces cerevisiae, and vestitone reductase from Medicago sativa (alfalfa) (Guo and Paiva 1995). All of these proteins share with protein 3 several conserved regions; an alignment with simred, DFR, and vestitone reductase is shown in Figure 8.

The amino-terminal 400 amino acids of protein 3 are $25 \%$ identical with DFR, but the carboxyterminal 74 amino acids do not match well with any sequences in the databases. The PSORT program (Nakai and Kanehisa 1992) indicated a high scoring (0.88) nuclear localization signal sequence in this region (Fig. 8). Analysis by the PSITE program (Solovyev and Kolchanov 1994) revealed an exact match to a consensus ATP/GTP binding site (P-loop; amino acids 409-416; probability of random occurrence, $<0.05$ ).

Comparison of Coomassie stained 2-D gels of ${ }^{32}$ P-labeled proteins with their autoradiographs indicates that the more acidic form of protein 3 is a phosphoprotein while the basic form of protein 3 is unphosphorylated. The PSITE program detected four potential PKC phosphorylation sites and nu- merous casein kinase II sites; these are, however, common motifs.

The tissue distribution of protein 3 mRNA was evaluated using RPAs (Fig. 9). For each tissue, $4 \mu \mathrm{g}$ of total RNA was assayed with probes for protein 3 and HSC70. Protein 3 mRNA is highly expressed in the nervous system, with lesser levels of expression in penis $>$ body wall $>$ kidney $>>$ ovitestis $>$ heart $>$ gill. None was detected in hepatopancreas.

\section{PROTEIN 4 REMAINS UNIDENTIFIED}

No in situ-labeled protein matched the $M_{\mathrm{r}}$ and pI of protein 4. However, as noted above, the addition of microsomal membranes to the lysate altered the $M_{\mathrm{r}}$ and $\mathrm{pI}$ of some proteins. Protein 4 was among those that were affected, indicating that it may be a secreted or integral membrane protein. Alternative strategies must be devised to identify the mRNA coding for this protein.

5-HT INCREASED ALL THREE IDENTIFIED mRNAS IN PLEURAL SENSORY NEURONS

Our primary interest in detecting mRNA

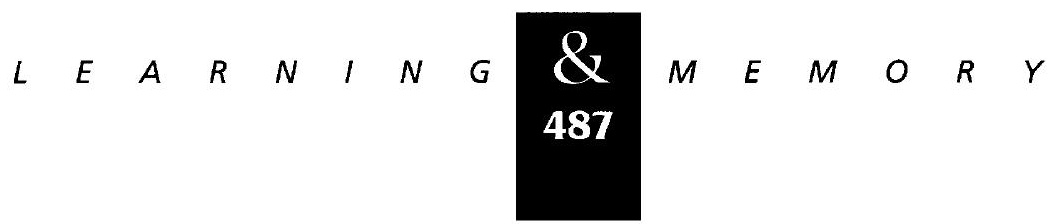




\begin{tabular}{|c|}
\hline $\begin{array}{l}\text { rot } 3 \\
\text { simred } \\
d \text { fr arab } \\
\text { vest }\end{array}$ \\
\hline $\begin{array}{l}\text { r rot } 3 \\
\text { simred } \\
d f r \text { arab } \\
v \in s t\end{array}$ \\
\hline $\begin{array}{l}\text { rot } 3 \\
\text { simred } \\
\text { d fr_arab } \\
\text { vest }\end{array}$ \\
\hline $\begin{array}{l}\text { rot } 3 \\
\text { simred } \\
d \mathrm{fr}^{\mathrm{a}} \mathrm{rab} \\
\text { vest }\end{array}$ \\
\hline $\begin{array}{l}\text { rot } 3 \\
\text { simred } \\
\text { d fr arab } \\
\text { vest }\end{array}$ \\
\hline $\begin{array}{l}\text { prot } 3 \\
\text { simred } \\
\text { d fr.arab } \\
\text { vest }\end{array}$ \\
\hline $\begin{array}{l}\text { prot } 3 \\
\text { simred } \\
d \text { fr arab } \\
v \in s t\end{array}$ \\
\hline $\begin{array}{l}\text { rot } 3 \\
\text { simred } \\
\text { der arab } \\
\text { vest }\end{array}$ \\
\hline 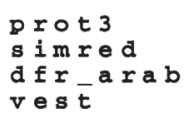 \\
\hline
\end{tabular}

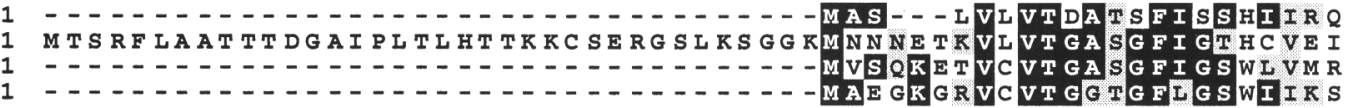

22 LQEDGCQVRGTVSSLSDEEERIKVLHELC PEAKFKVEVVEADPAKRESWESAMKDVQYVI 61 L IRNG YR VR GTVR-DLNNRAKVQPIKKLD--KKNHLELVEADLLDSTCWKKAVAGCDYVL 25 L I ERG Y F VRATVR-D PGNLKKVQHLLDLPN-AKTQLTLWRADLSEEGSTDDAINGCDGVF

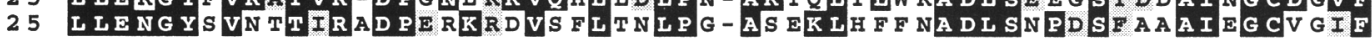

82 LAIKPTA AVPAATEGEA T QPAVEA VLNVFKACVAAKSVRRVVLTSSYQAVCG-- - - 118 HVASPFP IVSDER-- C T TTAVEGTMNVLKAIAEDGNVRKLVLTSSCAAVNGLWSLIQN

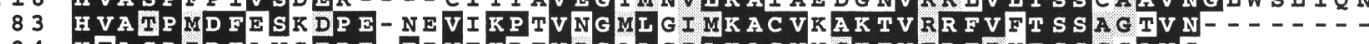

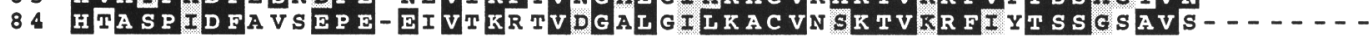

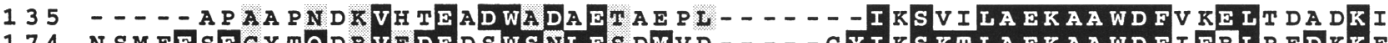

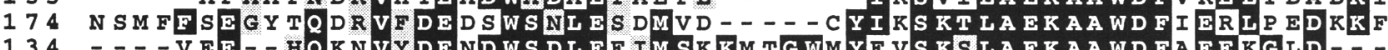

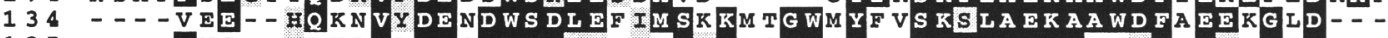

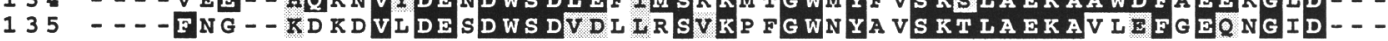

183 E LCVMNPTMPLGPPLIDAQHDIVRTLLDRGITGCPRVCY SV - - - VDVRDVATAHAKALT 229 PMTVINPTLVEGPAYITEQGASITLMRKFMNGEMPAAPPLN M P IVDVRDVALAHEEAMR 185 - FI SIIPTLVVGPFITTSMPPSLITAISPITRNEAHYSI IRQGQYVHLDDLCNAHIF LYE 186 - VVTIILPFIVGREVCPKLPDSIEKALVLVLGKKEQIGVTR-FHMVHVDDVARAHIYLLE

239 L DEVAGNRH IL H AN LWVKDAALALSKEFRPFGYSTPTISLPNVA LWGLSLFNKTARTFI 288 - RPESDNERIIV-.......... IKMVKCYWIP RFTA PY FF VRLYALFDPETKASI 244 QA AAKGRY ICS244 - NS VPGGRYNCS- . - . . . - PEIVPIEEMSQLLSAKYPEYQIITVDEIKEIKG

Figure 8: Alignment of the amino acid sequence of protein 3 with a $C$. elegans ORF (simred), dihydroflavonol reductase (dfr_arab), and vestitone reductase (vest). The amino acids printed on black background are identical in at least two of the proteins. The shaded amino acids are conservative substitutions. The underlined sequences of protein 3 indicate a potential A/GTP binding site and a potential nuclear localization signal.

changes in the pleural-pedal ganglia was to find mRNAs that might be involved in LTF, as expressed

\section{NS GL HT BW KD HP PN OT}

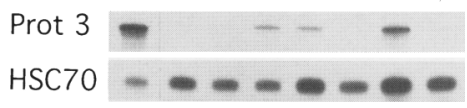

Figure 9: Tissue distribution of protein 3 mRNA. RPAs were performed using probes for protein 3 and HSC70. RNA was analyzed from nervous system (NS), gill (GL), heart $(\mathrm{HT})$, body wall (BW), kidney (KD), hepatopancreas (HP), penis (PN), and ovotestis (OT). A shorter film exposure is shown for nervous system because of the high level of expression of protein 3 mRNA. by the pleural sensory neurons. Therefore, we investigated the effect of 5-HT on the three identified mRNAs in the pleural sensory neurons using RPAs. Pleural-pedal ganglia were treated with 5-HT as in the IVT experiments. Ganglia were frozen at the end of $1.5 \mathrm{hr}$, pleural sensory neurons were removed, and RNA was extracted. HSC70 was used to normalize the amount of target mRNA in the RPAs. Several studies have found that $\mathrm{HSC} 70$ mRNA is unchanged by 5-HT in these cells (Kennedy et al. 1992; Kuhl et al. 1992; Hu et al. 1993; Liu et al. 1997). All three mRNAs that had increased in ganglia, as determined by IVT, also increased in the sensory neurons, as determined by

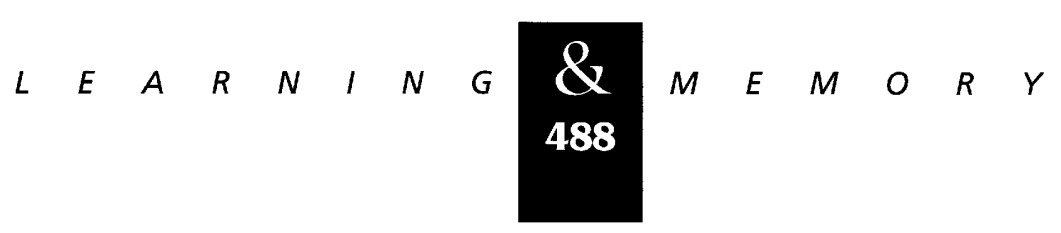


RPA (Fig. 10; Table 1). The mRNA for aldolase-B, another glycolytic enzyme, was also measured and was found to be unchanged after $1.5 \mathrm{hr}$ of $5-\mathrm{HT}$ treatment. RPA results for Aplysia tolloid/bone morphogenetic protein-1-like protein (apTBL-1) are included in Table 1 for comparison (Liu et al. 1997).

BEHAVIORAL TRAINING INCREASED CaM AND PROTEIN 3 IN PLEURAL SENSORY NEURONS

Although 5-HT has been used as an in vitro analog of sensitization training, bath-applied 5-HT may not mimic behavioral training exactly. To further evaluate the potential role of these proteins in long-term sensitization and facilitation, we measured mRNA changes in sensory neurons following behavioral training. Animals received four blocks of shocks over $1.5 \mathrm{hr}$ to one side of the body as previously described (Scholz and Byrne 1987; W.L. Lee, M. Aguirre, L.J. Cleary, and J.H. Byrne, unpubl.). Sensory neurons from the trained side of the animal were compared to the untrained side. Using RPAs, we found that $\mathrm{CaM}$ and protein 3 mRNA were increased in the sensory neurons following training, whereas PGK mRNA was unchanged (Table 1).

\section{ELECTRICAL STIMULATION INCREASED}

THE INCORPORATION OF LABELED AMINO ACIDS

INTO THE IDENTIFIED PRO'TEINS IN PLEURAL SENSORY NEURONS

If the mRNAs identified above are involved in the generation of LTF, we would expect the synthesis of their encoded proteins to increase during the time shown previously to be sensitive to inhibitors of protein synthesis (Montarolo et al. 1986). To investigate the changes in protein synthesis in

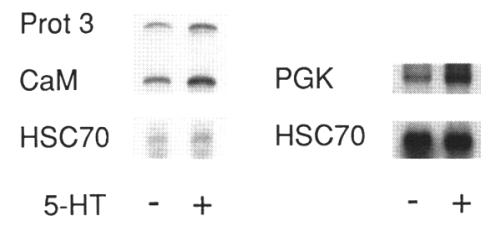

Figure 10: Examples of RPAs showing the effects of 5-HT on mRNAs coding for CaM, PGK, and protein 3 in pleural sensory neurons. Riboprobes were hybridized to RNA extracted from sensory neurons of four to six

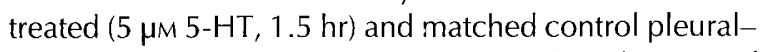
pedal ganglia. HSC70 was used to normalize the ODs of the other protected fragments (see Table 1). sensory neurons, we used electrical stimulation of nerves of isolated pleural-pedal ganglia as an in vitro analog of sensitization training. This technique mimics many of the effects of behavioral training and exposure of ganglia to 5-HT and analogs of cAMP (Mercer et al. 1991; Noel et al. 1991, 1993; Zhang et al. 1994; J.R. Goldsmith and J.H. Byrne, unpubl.). Analysis by 2-D PAGE of sensory neuron proteins showed that electrical stimulation of peripheral nerves over a 1.5-hr period produced large increases in the incorporation of labeled amino acid into $\mathrm{CaM}$, when measured at the end of stimulation (Fig. 11) $(+166 \% ; P<0.01, \mathrm{VQ}=98$, $n=8)$. Incorporation of label into PGK $(+53 \%$; $P<0.01, \mathrm{VQ}=94, n=10)$ and protein $3(+30 \%$; $P<0.01, \mathrm{VQ}=72, n=10)$ was also increased at the end of stimulation (Fig. 11).

\section{Discussion}

Using IVT of mRNA from pleural-pedal ganglia we found that 5-HT treatments capable of producing LTF in sensory neurons increased the level of translatable message for three proteins and decreased the message for another. After cloning cDNAs for the three increased mRNAs, we used RPAs to examine the levels of these mRNAs in pleural sensory neurons. The levels of mRNA for CaM, PGK, and protein 3 were increased in pleural sensory neurons by 5-HT, whereas only CaM and protein 3 mRNAs were increased by sensitization training. In addition, electrical stimulation of peripheral nerves of the pleural-pedal ganglia, an in vitro ana$\log$ of long-term sensitization, increased incorporation of labeled amino acid into all three proteins. Because increased incorporation of labeled amino acids does not demonstrate an increase in total protein, further studies will be needed to determine the actual increase in protein.

CaM

Protein 1 was identified as CaM by antisense knockout of mRNA for CaM prior to IVT, binding of protein 1 by anti-rat CaM antibody, and comigration of protein 1 with chicken CaM. Changes in CaM mRNA levels in response to external stimuli have been reported in other systems. Some of these stimuli have radical effects on cells, including the induction of differentiation (Bai and Weiss 1991; Bai et al. 1992), apoptosis (Dowd et al. 1991), and muscle atrophy (Nishikawa and Kay 


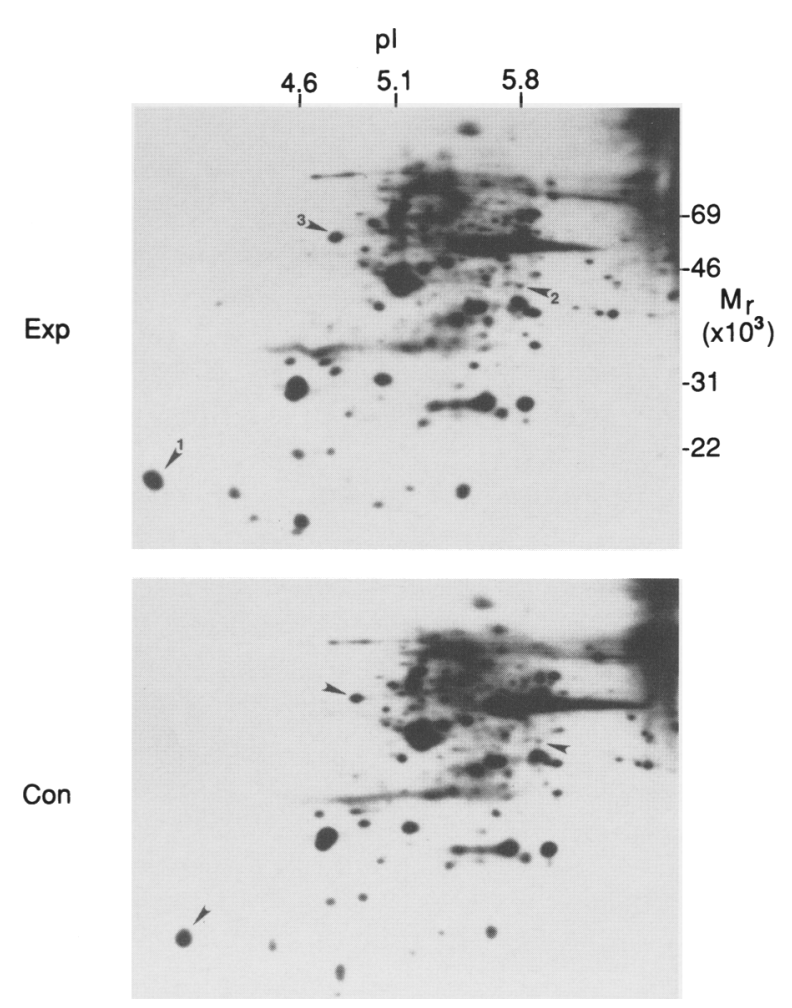

Figure 11: Effect of nerve stimulation on the incorporation of $\left[{ }^{35} \mathrm{~S}\right]$ methionine into $\mathrm{CaM}, \mathrm{PGK}$, and protein 3 in pleural sensory neurons. Experimental ganglia were stimulated over a 1.5 -hr period. The label was applied over a 2-hr period beginning 0.5 -hr before stimulation. The ganglia were then frozen and the pleural sensory neurons removed. Proteins were analyzed by 2-D PAGE and densitometry. The incorporation into proteins 1,2 , and 3 was increased after stimulation (Exp), as compared to unstimulated controls (Con). In this series of experiments, we focused our attention only on proteins 1,2 , and 3. Proteins other than 1,2, and 3 appear to be affected by electrical stimulation. Some of these additional effects are reproducible and have been reported in an earlier study (Noel et al. 1993).

1991). Reserpine and adrenalectomy have been reported to alter CaM mRNA levels in brain stem (Ni and Brown 1993) and pituitary (Gannon and McEwen 1994), respectively, whereas glucocorticoid suppression of ACTH release by AtT20 cells is associated with an increase in CaM mRNA (Shipston and Antoni 1992). In light of the rarity of cases in which CaM levels are altered in differentiated cells, our finding that 5-HT or training increased CaM mRNA suggests that this protein might have a key role, beyond its usual importance in cell function, in the sensory neurons.

It should be noted that Bergold et al. (1992) found that CaM mRNA levels do not appear to be elevated in Aplysia neurons $24 \mathrm{hr}$ after treatment. Therefore, the changes in CaM mRNA expression that we observed $1.5 \mathrm{hr}$ after treatment may be transient, as is true for the mRNA of apTBL-1 (Liu et al. 1997). Further study is needed to precisely define the time course of the change in expression of CaM mRNA, as well as the time course of expression for the other mRNAs.

CaM can influence a variety of cell functions (for review, see Means 1988; Means et al. 1991; Bachs et al. 1994; Gnegy 1995), and numerous CaM-regulated enzymes have been found in Aplysia neurons (Novak-Hofer and Levitan 1983; Saitoh and Schwartz 1983, 1985; DeRiemer et al. 1984; Kramer et al. 1988; Eliot et al. 1989; Abrams et al. 1991; Endo et al. 1992; K.A. Ocorr and J.H. Byrne, unpubl.). Because CaM is constitutively expressed at a high level, how might an increase in CaM level affect cell function? Neurons contain a high level of $\mathrm{Ca}^{2+}$-independent CaM-binding proteins, which may keep the level of free CaM low (Gnegy 1995). An increase in $\mathrm{CaM}$ without a concomitant increase in these proteins could increase the level of free CaM and might enhance the response of CaM effectors to $\mathrm{Ca}^{2+}$.

One attractive hypothesis is that CaM acts through $\mathrm{Ca}^{2+} / \mathrm{CaM}$-dependent protein kinase II (CaMK II) to enhance synaptic release (Llinas et al. 1985, 1991; Lin et al. 1990; Nichols et al. 1990). However, although CaMK II seems to have a role in modulating sensory neuron transmitter release ( $\mathrm{Na}$ kanishi et al. 1997), the inhibitor KN-62 did not block the induction of LTF nor did it affect the enhanced EPSP when tested $24 \mathrm{hr}$ after induction of LTF (F. Zhang, K. Nakanishi, D.A. Baxter, S. Hattar, Q.-R. Liu, K. MacPhee, A. Eskin, and J.H. Byrne, unpubl.). Nonetheless, CaM might induce LTF through one of the other effectors noted above.

PGK

A partial peptide sequence of protein 2 led to the cloning of PGK from an Aplysia library. Analysis by RPAs confirmed that the PGK mRNA was increased in sensory neurons in response to 5-HT. PGK catalyzes the formation of ATP from 1,3-bisphosphoglycerate in the glycolytic pathway, as well as the reverse reaction in gluconeogenesis. The increased production of this protein could accommodate the increased energy demand on the cell from growth-related processes and increased activity. A small but significant increase (17\%) in

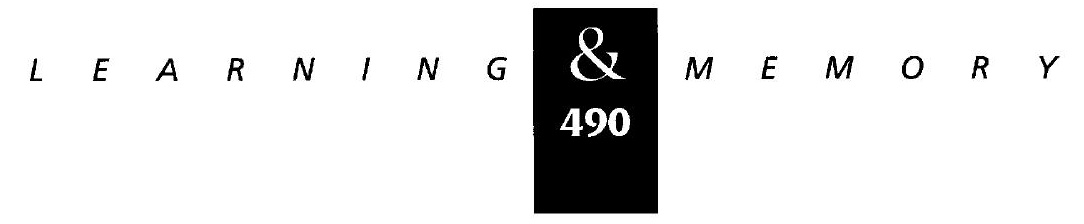


glucose utilization has been detected in sensory neurons at the end of treatment with 5-HT for 1.5 hr (R. Homayouni and A. Eskin, unpubl.). Although the mammalian PGK I gene is induced by hypoxia (Firth et al. 1994; Semenza et al. 1994; Hui et al. 1996) and PGK II is induced during spermatogenesis (McCarrey and Thomas 1987), this appears to be the first report of the regulation of PGK expression by a neurotransmitter.

We also found that aldolase-B mRNA was not increased by $5-\mathrm{HT}$, suggesting that the increase in PGK may not be part of a general up-regulation of glycolytic enzymes. PGK and other enzymes involved in energy metabolism have alternative functions (Williams et al. 1985; Meyer-Siegler et al. 1991; Marchase et al. 1993; N.A. Veyna and R.B. Marchase; N.A. Veyna, P. Bounelis, and R.B. Marchase, both unpubl.). With Annexin II, PGK forms a primer recognition complex involved in DNA replication (Jindal and Vishwanatha 1990; Kumble and Vishwanatha 1991). Although DNA replication is unlikely to be important for facilitation, this evidence supports the possibility of other roles for PGK.

PGK mRNA was increased in the sensory neurons by 5 -HT, and PGK protein was increased by electrical stimulation; however, PGK mRNA was not increased by sensitization training. All of the mRNAs that we have studied so far increased less after sensitization training than they increased after treatments with 5-HT (Table 1; compare RPA results). Longer or more intense training, which can produce sensitization lasting for days (Pinsker et al. 1973; Frost et al. 1985), may be necessary to produce an increase in PGK mRNA.

\section{PROTEIN 3}

Peptide sequencing and PCR with degenerate primers produced a probe that was used to clone protein 3 from an Aplysia cDNA library. RPAs confirmed that the mRNAs for this protein were increased by 5 -HT and sensitization training. Protein 3 is unique but contains several regions that are conserved in plant reductases (Fig. 8). The reductase domain is also shared with a $C$. elegans ORF. Plant reductases comprise a superfamily with animal steroid dehydrogenases (Baker and Blasco 1992). Protein 3 and the $C$. elegans ORF are the only animal genes identified to date with greater sequence similarity to the plant reductases than to the steroid dehydrogenases.

Sequence analyses detected several interesting features in the carboxy-terminal domain of protein 3 , including a strong nuclear localization signal found near the carboxyl terminus. However, protein 3 has no obvious DNA-binding or other transcription factor-like sequence. Another structure identified is a P-loop, a type of nucleotide binding site found in several families of A/GTP binding proteins (Saraste et al. 1990). Protein 3 does not share any other similarities with these families of proteins.

Protein 3 appears to exist in a phosphorylated and an unphosphorylated form. The PSITE program detected four potential protein kinase $C$ (PKC) sites and numerous casein kinase II sites, but these consensus sequences occur frequently and may not be phosphorylated. Previous studies did not detect an increase in phosphorylation of protein 3 following treatment with phorbol diacetate, an activator of $\mathrm{PKC}$, nor after treatment with 5-HT (Homayouni et al. 1995), which also activates PKC in sensory neurons (Sossin and Schwartz 1992). In future studies it will be of interest to determine which sites are phosphorylated.

\section{MOLECULAR CHANGES IN LTF AND SENSITIZATION}

A model of molecular events involved in longterm sensitization predicts that changes in gene expression will occur over various time intervals (Goelet et al. 1986). The discovery of immediateearly [C/EBP (Alberini et al. 1994); ubiquitin hydrolase (Hegde et al. 1997)], early [apTBL-1 (Liu et al. 1997); CaM, PGK, protein 3], and late [calreticulin (Kennedy et al. 1992); BiP (Kuhl et al. 1992)] increases in mRNA levels with training or 5-HT lends support to this model. However, the techniques used in these studies do not confirm that increased transcription was responsible for the observed increase in mRNA. Furthermore, changes in the expression of these proteins must still be linked to the increase in transmitter release and morphological changes that occur with long-term sensitization.

Recent studies have begun to define intermediate forms of facilitation (Sossin et al. 1994; Ghirardi et al. 1995; Mauelshagen et al. 1996) and facilitation that persists $48 \mathrm{hr}$ after a single series of stimulations (Zhang et al. 1994, 1997). Treatments for establishing LTF without producing short-term facilitation have also been described (Emptage and Carew 1993). Analyzing proteins and mRNAs using these alternative protocols could provide additional information about previously identified pro-

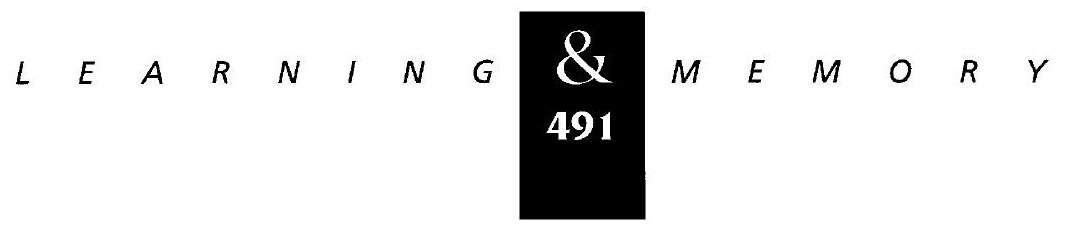


teins, as well as reveal other proteins that may be involved in LTF and sensitization.

Although progress has been made in determining the molecular changes in sensory neurons in response to 5-HT and sensitizing stimuli, the list of regulated genes remains short. Furthermore, the increases in mRNA expression following single training sessions are modest: All increase $<100 \%$. Small changes in expression might be sufficient to alter sensory neuron function, but other important changes may yet remain undetected.

\section{Acknowledgments}

We thank A.R. Means for CaM antibody and CaM protein, and for providing us with technical advice. We thank P. Dash and A. Kurosky for cDNA libraries, R.S. Molday for PGK antibody, K. Kuhl and E.R. Kandel for the $\mathrm{HSC70}$ clone, and R. Cook for peptide sequencing. We also thank Chun Wang for technical help. This work was supported by National Institutes of Health grants NS 28462 (to A.E.) and NS 19895 (to J.H.B.), National Institutes of Mental Health award K05 MH00649 (to J.H.B.), and Air Force Office of Scientific Research grant F49620-92-J-0494 (to A.E.).

The publication costs of this article were defrayed in part by payment of page charges. This article must therefore be hereby marked "advertisement" in accordance with 18 USC section 1734 solely to indicate this fact.

\section{References}

Abrams, T.W., K.A. Karl, and E.R. Kandel. 1991. Biochemical studies of stimulus convergence during classical conditioning in Aplysia: Dual regulation of adenylate cyclase by $\mathrm{Ca}^{2+} /$ calmodulin and transmitter. J. Neurosci. 11: 2655-2665.

Alberini, C.M., M. Ghirardi, R. Metz, and E.R. Kandel. 1994. $C / E B P$ is an immediate-early gene required for the consolidation of long-term facilitation in Aplysia. Cell 76: $1-20$.

Altschul, S.F., W. Gish, W. Miller, E.W. Myers, and D.J. Lipman. 1990. Basic local alignment search tool. J. Mol. Biol. 215: 403-410.

Anokhin, K. and S.P.R. Rose. 1991. Learning induced increase of immediate early gene messenger RNA in the chick forebrain. Eur. J. Neurosci. 3: 162-167.

Bachs, O., N. Agell, and E. Carafoli. 1994. Calmodulin and calmodulin-binding proteins in the nucleus. Cell Calcium 16: 289-296.

Bai, G. and B. Weiss. 1991. The increase of calmodulin in PC1 2 cells induced by NGF is caused by differential expression of multiple mRNAs for calmodulin. J. Cell Physiol. 149: 414-421.

Bai, G., R.A. Nichols, and B. Weiss. 1992. Cyclic AMP selectively up-regulates calmodulin genes I and II in PC12 cells. Biochim. Biophys. Acta 1130: 189-196.

Baker, M.E. and R. Blasco. 1992. Expansion of the mammalian 3 $\beta$-hydroxysteroid dehydrogenase/plant dihydroflavonol reductase superfamily to include a bacterial cholesterol dehydrogenase, a bacterial UDP-galactose-4-epimerase and open reading frames in vaccinia virus and fish lymphocystis disease virus. FEBS Lett. 301: 89-93.

Barzilai, A., T.E. Kennedy, J.D. Sweatt, and E.R. Kandel. 1989. 5-HT modulates protein synthesis and the expression of specific proteins during long-term facilitation in Aplysia sensory neurons. Neuron 2: 1577-1586.

Bergold, P.J., S.A. Beushausen, T.C. Sacktor, S. Cheley, H. Bayley, and J.H. Schwartz. 1992. A regulatory subunit of the cAMP-dependent protein kinase down-regulated in Aplysia sensory neurons during long-term sensitization. Neuron 8: $387-397$.

Bourtchuladze, R., B. Frenguelli, J. Blendy, D. Cioffi, G. Shutz, and A.J. Silva. 1994. Deficient long-term memory in mice with a targeted mutation of the CAMP-responsive element-binding protein. Cell 79: 59-68.

Byrne, J.H., R.E. Zwartjes, R. Homayouni, S.D. Critz, and A. Eskin. 1993. Roles of second messenger pathways in neuronal plasticity and in learning and memory: Insights gained from Aplysia. Adv. Second Messenger Phosphoprotein Res. 27: 1-62.

Castellucci, V.F. and S. Schacher. 1990. Synaptic plasticity and behavioral modifications in the marine mollusk Aplysia. Prog. Brain Res. 86: 105-115.

Chomczynski, P. and N. Sacchi. 1987. Single-step method of RNA isolation by acid guanidinium thiocyanate-phenol-chloroform extraction. Anal. Biochem. 162: 156-159.

Ciccarese, S., S. Tommasi, and G. Vonghia. 1989. Cloning and CDNA sequence of the rat X-chromosome linked phosphoglycerate kinase. Biochem. Biophys. Res. Commun. 165: $1337-1344$.

Colbert, R.A. and D.A. Young. 1986. Glucocorticoid-induced messenger ribonucleic acids in rat thymic lymphocytes: Rapid primary effects specific for glucocorticoids. Endocrinology 119: 2598-2605.

1987. Detection of mRNAs coding for translationally regulated heat-shock proteins in non-heat-shocked thymic lymphocytes. J. Biol. Chem. 262: 9939-9941.

Coleclough, C., L. Kuhn, and I. Lefkovits. 1990. Regulation of mRNA abundance in activated T lymphocytes: Identification of mRNA species affected by the inhibition of protein synthesis. Proc. Natl. Acad. Sci. 87: 1753-1757.

Dash, P.K., B. Hochner, and E.R. Kandel. 1990. Injection of the CAMP-responsive element into the nucleus of Aplysia sensory neurons blocks long-term facilitation. Nature 345: 718-721.

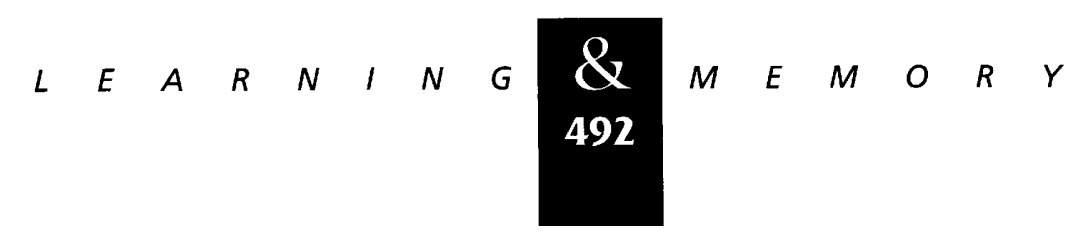


Davis, H.P. and L.R. Squire. 1984. Protein synthesis and memory: A review. Psychol. Bull. 96: 518-559.

DeRiemer, S.A., L.K. Kaczmarek, Y. Lai, T.L. McGuinness, and P. Greengard. 1984. Calcium/calmodulin-dependent protein phosphorylation in the nervous system of Aplysia. J. Neurosci. 4: 1618-1625.

Dowd, D.R., P.N. MacDonald, B.S. Komm, M.R. Haussler, and R. Miesfeld. 1991. Evidence for early induction of calmodulin gene expression in lymphocytes undergoing glucocorticoid-mediated apoptosis. J. Biol. Chem. 266: 18423-18426.

Eliot, L.S., Y. Dudai, E.R. Kandel, and T.W. Abrams. 1989. $\mathrm{Ca}^{2+} /$ calmodulin sensitivity may be common to all forms of neural adenylate cyclase. Proc. Natl. Acad. Sci. 86: $9564-9568$.

Emptage, N.J. and T.J. Carew. 1993. Long-term synaptic facilitation in the absence of short-term facilitation in Aplysia neurons. Science 262: 253-256.

Endo, S., S. Shenolikar, A. Eskin, R.E. Zwartjes, and J.H. Byrne. 1992. Characterization of neuronal protein phosphatases in Aplysia californica. J. Neurochem. 58: $975-982$.

Eskin, A., K.S. Garcia, and J.H. Byrne. 1989. Information storage in the nervous system of Aplysia: Specific proteins affected by serotonin and CAMP. Proc. Natl. Acad. Sci. 86: $2458-2462$.

Firth, J.D., B.L. Ebert, C.W. Pugh, and P.J. Ratcliffe. 1994. Oxygen-regulated control elements in the phosphoglycerate kinase 1 and lactate dehydrogenase A genes: Similarities with the erythropoietin 3' enhancer. Proc. Natl. Acad. Sci. 91: 6496-6500.

Frost, W.N., V.F. Castellucci, R.D. Hawkins, and E.R. Kandel. 1985. Monosynaptic connections made by the sensory neurons of the gill- and siphon-withdrawal reflex in Aplysia participate in the storage of long-term memory for sensitization. Proc. Natl. Acad. Sci. 82: 8266-8269.

Gannon, M.N. and B.S. McEwen. 1994. Distribution and regulation of calmodulin mRNAs in rat brain. Mol. Brain Res. 22: 186-192.

Ghirardi, M., P.G. Montarolo, and E.R. Kandel. 1995. A novel intermediate stage in the transition between short- and long-term facilitation in the sensory to motor neuron synapse of Aplysia. Neuron 14: 413-420.

Gnegy, M.E. 1995. Calmodulin: Effects of cell stimuli and drugs on cellular activation. Prog. Drug Res. 45: 33-65.

Goelet, P., V.F. Castellucci, S. Schacher, and E.R. Kandel. 1986. The long and the short of long-term memory-A molecular framework. Nature 322: 419-422.

Gross, M., M.S. Rubino, and T.K. Starn. 1988. Regulation of protein synthesis in rabbit reticulocyte lysate. J. Biol. Chem. 263: 12486-12492.
Guo, L. and N.L. Paiva. 1995. Molecular cloning and expression of alfalfa (Medicago sativa L.) vestitone reductase, the penultimate enzyme in medicarpin biosynthesis. Arch. Biochem. Biophys. 320: 353-360.

Hegde, A.N., K. Inokuchi, P. Wanzheng, A. Casadio, M. Ghirardi, D.G. Chain, K.C. Martin, E.R. Kandel, and J.H. Schwartz. 1997. Ubiquitin C-terminal hydrolase is an immediate-early gene essential for long-term facilitation in Aplysia. Cell 89: 115-126.

Homayouni, R., J.H. Byrne, and A. Eskin. 1995. Dynamics of protein phosphorylation in sensory neurons of Aplysia. J. Neurosci. 15: 429-438.

Hsu, S.-C. and R.S. Molday. 1991. Glycolytic enzymes and a GLUT-1 glucose transporter in the outer segments of rod and cone photoreceptor cells. J. Biol. Chem. 266: 21745-21752.

Hu, Y., A. Barzilai, M. Chen, C.H. Bailey, and E.R. Kandel. 1993. 5-HT and cAMP induce the formation of coated pits and vesicles and increase the expression of clathrin light chain in sensory neurons of Aplysia. Neuron 10: 921-929.

Hui, L., H.P. Ko, and J.P. Whitlock. 1996. Induction of phosphoglycerate kinase 1 gene expression by hypoxia. J. Biol. Chem. 271: 21262-21267.

Jindal, H.K. and J.K. Vishwanatha. 1990. Functional identity of a primer recognition protein as phosphoglycerate kinase. J. Biol. Chem. 265: 6540-6543.

Kennedy, T.E., M.A. Gawinowicz, A. Barzilai, E.R. Kandel, and J.D. Sweatt. 1988. Sequencing of proteins from two-dimensional gels by using in situ digestion and transfer of peptides to polyvinylidene difluoride membranes: Application to proteins associated with sensitization in Aplysia. Proc. Natl. Acad. Sci. 85: 7008-7012.

Kennedy, T.E., D. Kuhl, A. Barzilai, J.D. Sweatt, and E.R. Kandel. 1992. Long-term sensitization training of Aplysia leads to an increase in calreticulin, a major presynaptic calcium-binding protein. Neuron 9: 1013-1024.

Kramer, R.H., E.S. Levitan, M.P. Wilson, and I.B. Levitan. 1988. Mechanism of calcium-dependent inactivation of a potassium current in Aplysia neuron R15: Interaction between calcium and cyclic AMP. J. Neurosci. 8: 1804-1813.

Kuhl, K., T.E. Kennedy, A. Barzilai, and E.R. Kandel. 1992. Long-term sensitization training in Aplysia leads to an increase in the expression of $\mathrm{BiP}$, the major protein chaperon of the endoplasmic reticulum. J. Cell Biol. 119: 1069-1076.

Kumble, K.D. and J.K. Vishwanatha. 1991. Immunoelectron microscopic analysis of the intracellular distribution of primer recognition proteins, annexin 2 and phosphoglycerate kinase, in normal and transformed cells. J. Cell Sci. 99: 751-758.

Lin, J.-W., M. Sugimori, R.R. Llinas, T.L. McGuinness, and P. Greengard. 1990. Effects of synapsin I and calcium/ calmodulin-dependent protein kinase II on spontaneous neurotransmitter release in the squid giant synapse. Proc. Natl. Acad. Sci. 87: 8257-8261.

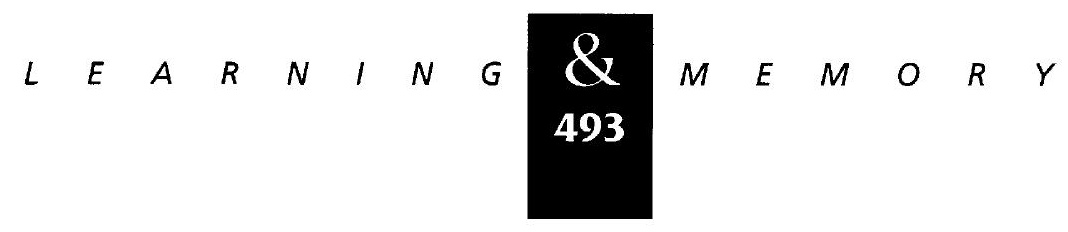




\section{Zwartjes et al.}

Liu, Q.-R., S. Hattar, S. Endo, K. MacPhee, H. Zhang, L. Cleary, J.H. Byrne, and A. Eskin. 1997. A developmental gene (Tolloid/BMP-1) is regulated in Aplysia neurons by treatments that induce long-term sensitization. J. Neurosci. 17: 755-764.

Llinas, R.R., T.L. McGuinness, C.S. Leonard, M. Sugimori, and P. Greengard. 1985. Intraterminal injection of synapsin I or calcium/calmodulin-dependent protein kinase II alters neurotransmitter release at the squid giant synapse. Proc. Natl. Acad. Sci. 82: 3035-3039.

Llinas, R.R., J.A. Gruner, M. Sugimori, T.L. McGuinness, and P. Greengard. 1991. Regulation by synapsin I and $\mathrm{Ca}^{2+}$-calmodulin-dependent protein kinase II of transmitter release in squid giant synapse. J. Physiol. 436: 257-282.

Marchase, R.B., P. Bounelis, L.M. Brumley, N. Dey, B. Browne, D. Auger, T. Fritz, P. Kulesza, and D.M. Bedwell. 1993. Phosphoglucomutase in Saccharomyces cerevisiae is a cytoplasmic glycoprotein and the acceptor for a Glc-phosphotransferase. J. Biol. Chem. 268: 8341-8349.

Mauelshagen, J., G.R. Parker, and T.J. Carew. 1996. Dynamics of induction and expression of long-term synaptic facilitation in Aplysia. J. Neurosci. 16: 7099-7108.

McCarrey, J.R. and K. Thomas. 1987. Human testis-specific PGK gene lacks introns and possesses characteristics of a processed gene. Nature 326: 501-505.

Means, A.R. 1988. Molecular mechanisms of action of calmodulin. Recent Prog. Horm. Res. 44: 223-259.

Means, A.R., M.F.A. VanBerkum, I. Bagchi, K.P. Lu, and C.D. Rasmussen. 1991. Regulatory functions of calmodulin. Pharmac. Ther. 50: 255-270.

Mercer, A.R., N.J. Emptage, and T.J. Carew. 1991. Pharmacological dissociation of modulatory effects of serotonin in Aplysia sensory neurons. Science 254: 1811-1813.

Meyer-Siegler, K., D.J. Mauro, G. Seal, J. Wurzer, J.K. deRiel, and M.A. Sirover. 1991. A human nuclear uracil DNA glycosylase is the $37-\mathrm{kDa}$ subunit of glyceraldehyde-3-phosphate dehydrogenase. Proc. Natl. Acad. Sci. 88: 8460-8464.

Miles, M.F., J.E. Diaz, and V. DeGuzman. 1992. Ethanol-responsive gene expression in neural cell cultures. Biochim. Biophys. Acta 1138: 268-274.

Minshull, J. and T. Hunt. 1986. The use of single-stranded DNA and RNase $\mathrm{H}$ to promote quantitative "hybrid arrest of translation" of mRNA/DNA hybrids in reticulocyte cell-free translation. Nucleic Acids Res. 14: 6433-6451.

Montarolo, P.G., P. Goelet, V.F. Castellucci, J. Morgan, and E.R. Kandel. 1986. A critical period of macromolecular synthesis in long-term heterosynaptic facilitation in Aplysia. Science 234: 1249-1254.
Nagle, G.T., A.T. Garcia, S.L. Knock, E.L. Gorham, W.R. Van Heumen, and A. Kurosky. 1995. Molecular cloning, cDNA sequence, and localization of a prohormone convertase (PC2) from the Aplysia atrial gland. DNA Cell Biol. 14: 145-154.

Nakai, K. and M. Kanehisa. 1992. A knowledge base for predicting protein localization sites in eukaryotic cells. Genomics 14: 897-911.

Nakanishi, K., F. Zhang, D.A. Baxter, A. Eskin, and J.H. Byrne. 1997. Role of calcium-calmodulin dependent protein kinase II in modulation of sensorimotor synapses in Aplysia. J. Neurophysiol. 78: 409-416.

Nelson, T.J. and D.L. Alkon. 1990. Specific high molecular weight mRNAs induced by associative learning in Hermissenda. Proc. Natl. Acad. Sci. 87: 269-273.

$\mathrm{Ni}, \mathrm{B}$. and I.R. Brown. 1993. Modulation of a neuronal calmodulin mRNA species in the rat brain stem by reserpine. Neurochem. Res. 18: 185-192.

Nichols, R.A., T.S. Sihra, A.J. Czernik, A.C. Nairn, and P. Greengard. 1990. Calcium/calmodulin-dependent protein kinase II increases glutamate and noradrenaline release from synaptosomes. Nature 343: 647-651.

Nishikawa, B.K. and B.K. Kay. 1991. Neural regulation of calmodulin in adult Xenopus leg muscle. Cell Calcium 12: 683-693.

Noel, F., K.P. Scholz, A. Eskin, and J.H. Byrne. 1991. Common set of proteins in Aplysia sensory neurons affected by an in vitro analog of long-term sensitization training, 5-HT and cAMP. Brain Res. 568: 67-75.

Noel. F., M. Nuñez-Regueiro, R. Cook, J.H. Byrne, and A. Eskin. 1993. Long-term changes in synthesis of intermediate filament protein, actin and other proteins in pleural sensory neurons of Aplysia produced by an in vitro analog of sensitization training. Mol. Brain Res. 19: 203-210.

Novak-Hofer, I. and I.B. Levitan. 1983. $\mathrm{Ca}^{2+} /$ calmodulin-regulated protein phosphorylation in the Aplysia nervous system. J. Neurosci. 3: 473-481.

Pearson W.R. and D.J. Lipman. 1988. Improved tools for biological sequence comparison. Proc. Natl. Acad. Sci. 85: 2444-2448.

Pinsker, H., W.A. Hening, T.J. Carew, and E.R. Kandel. 1973. Long-term sensitization of a defensive withdrawal reflex in Aplysia. Science 182: 1039-1042.

Raju, U., M. Nuñez-Regueiro, R. Cook, M.A. Kaetzel, S.-C.J. Yeung, and A. Eskin. 1993. Identification of an annexin-like protein and its possible role in the Aplysia eye circadian system. J. Neurochem. 61: 1236-1245.

Saitoh, T. and J.H. Schwartz. 1983. Serotonin alters the subcellular distribution of a $\mathrm{Ca}^{2+} /$ calmodulin-binding protein in neurons of Aplysia. Proc. Natl. Acad. Sci. 80: 6708-6712. 
- 1985. Phosphorylation-dependent subcellular translocation of a $\mathrm{Ca}^{2+} /$ calmodulin-dependent protein kinase produces an autonomous enzyme in Aplysia neurons. J. Cell Biol. 100: 835-842.

Sambrook, J., E.F. Fritsch, and T. Maniatis. 1989. Molecular cloning: A laboratory manual, 2nd ed. Cold Spring Harbor Laboratory Press, Cold Spring Harbor, NY.

Saraste, M., P.R. Sibbald, and A. Wittinghofer. 1990. The P-loop-A common motif in ATP- and GTP-binding proteins. Trends Bioch. Sci. 15: 430-434.

Scholz, K.P. and J.H. Byrne. 1987. Long-term sensitization in Aplysia: Biophysical correlates in tail sensory neurons.

Science 235: 685-687.

Semenza, G.L., P.H. Roth, H.-M. Fang, and G.L. Wang. 1994. Transcriptional regulation of genes encoding glycolytic enzymes by hypoxia-inducible factor 1. J. Biol. Chem. 269: 23757-23763.

Shipston, M.J. and F.A. Antoni. 1992. Early glucocorticoid induction of calmodulin and its suppression by corticotropin-releasing factor in pituitary corticotrope tumor (AtT20) cells. Biochem. Biophys. Res. Commun. 189: 1382-1388.

Shirley, B.W., S. Hanley, and H.M. Goodman. 1992. Effects of ionizing radiation on a plant genome: Analysis of two Arabidopsis transparent testa mutations. Plant Cell 4: 333-347.

Solovyev, V.V. and N.A. Kolchanov. 1994. Search for functional sites using consensus. In Computer analysis of genetic macromolecules (ed. N.A. Kolchanov and H.A. Lim), pp. 16-21. World Scientific Publishing Co. Pte. Ltd., Singapore.

Sossin, W.S. and J.H. Schwartz. 1992. Selective activation of $\mathrm{Ca}^{2+}$-activated PKCs in Aplysia neurons by 5-HT. J. Neurosci. 12: $1160-1168$.

Sossin, W.S., T.C. Sacktor, and J.H. Schwartz. 1994. Persistent activation of PKC during the development of long-term facilitation in Aplysia. Learn. \& Mem. 1: 189-202.

Swanson. M.E., S.F. Sturner, and J.H. Schwartz. 1990.

Structure and expression of the Aplysia californica

calmodulin gene. J. Mol. Biol. 216: 545-553.

Sweatt, J.D. and E.R. Kandel. 1989. Persistent and transcriptionally-dependent increase in protein phosphorylation in long-term facilitation of Aplysia sensory neurons. Nature 339: 51-54.

Walter, P. and G. Blobel. 1983. Preparation of microsomal membranes for cotranslational protein translocation. Methods Enzymol. 96: 84-93.

Walters, E.T., J.H. Byrne, T.J. Carew, and E.R. Kandel. 1983a. Mechanoafferent neurons innervating tail of Aplysia. I.
Response properties and synaptic connections. J. Neurophysiol. 50: 1522-1542.

1983b. Mechanoafferent neurons innervating tail of Aplysia. II. Modulation by sensitizing stimulation. J. Neurophysiol. 50: 1543-1559.

Watson, H.C., N.P.C. Walker, P.J. Shaw, T.N. Bryant, P.L. Wendell, L.A. Fothergill, R.E. Perkins, S.C. Conroy, M.J. Dobson, M.F. Tuite, et al. 1982. Sequence and structure of yeast phosphoglycerate kinase. EMBO J. 1: 1635-1640.

Williams, K.R., S. Reddigari, and G.L. Patel. 1985. Identification of a nucleic acid helix-destabilizing protein from rat liver as lactate dehydrogenase-5. Proc. Natl. Acad. Sci. 82: 5260-5264.

Wilson, R., R. Ainscough, K. Anderson, C. Baynes, M. Berks, J. Bonfield, J. Burton, M. Connell, T. Copsey, J. Cooper, et al. 1994. 2.2 $\mathrm{Mb}$ of contiguous nucleotide sequence from chromosome III of C. elegans. Nature 368: 32-38.

Yin, J.C.P., J.S. Wallach, M. Del Vecchio, E.L. Wilder, H. Zhou, W.G. Quinn, and T. Tully. 1994. Induction of a dominant negative CREB transgene specifically blocks long-term memory in Drosophila. Cell 79: 49-58.

Zhang, F., J.R. Goldsmith, and J.H. Byrne. 1994. Neural analogue of long-term sensitization training produces long-term ( $24 \mathrm{hr}$ and $48 \mathrm{hr}$ ) facilitation of the sensory-to-motor neuron connection in Aplysia. J. Neurophysiol. 72: 778-784.

Zhang, F., S. Endo, L.J. Cleary, A. Eskin, and J.H. Byrne. 1997. Role of transforming growth factor- $\beta$ in long-term synaptic facilitation in Aplysia. Science 275: 1318-1320.

Zwartjes, R.E. and A. Eskin. 1990. Changes in protein phosphorylation in the eye of Aplysia associated with circadian rhythm regulation by serotonin. J. Neurobiol. 21: 376-383.

Received November 10, 1997; accepted in revised form January 23, 1998.

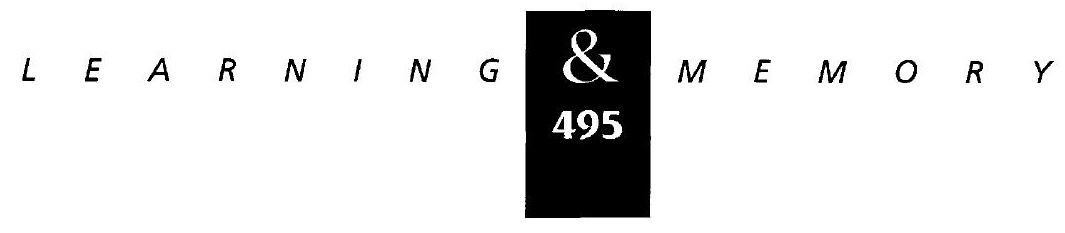




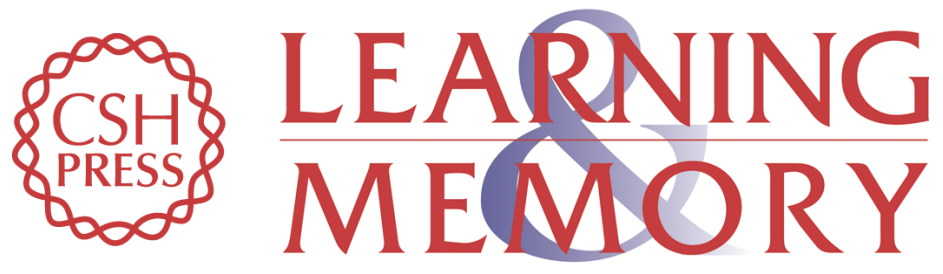

\section{Identification of specific mRNAs affected by treatments producing long-term facilitation in Aplysia.}

R E Zwartjes, H West, S Hattar, et al.

Learn. Mem. 1998, 4:

Access the most recent version at doi:10.1101//m.4.6.478

References This article cites 93 articles, 40 of which can be accessed free at: http://learnmem.cshlp.org/content/4/6/478.full.html\#ref-list-1

License

Email Alerting Receive free email alerts when new articles cite this article - sign up in the box at the Service top right corner of the article or click here. 